\title{
Analysis of aircraft and satellite measurements from the Intercontinental Chemical Transport Experiment (INTEX-B) to quantify long-range transport of East Asian sulfur to Canada
}

\author{
A. van Donkelaar ${ }^{1}$, R. V. Martin ${ }^{1,2}$, W. R. Leaitch ${ }^{3}$, A. M. Macdonald ${ }^{3}$, T. W. Walker ${ }^{1,4}$, D. G. Streets ${ }^{5}$, Q. Zhang ${ }^{5}$, \\ E. J. Dunlea ${ }^{6}$, J. L. Jimenez ${ }^{6}$, J. E. Dibb ${ }^{7}$, L. G. Huey ${ }^{8}$, R. Weber ${ }^{8}$, and M. O. Andreae ${ }^{9}$ \\ ${ }^{1}$ Dept. of Physics and Atmospheric Science, Dalhousie University, Canada \\ ${ }^{2}$ Harvard-Smithsonian Center for Astrophysics, USA \\ ${ }^{3}$ Science and Technology Branch, Environment Canada, Canada \\ ${ }^{4}$ Dept. of Physics, University of Toronto, Canada \\ ${ }^{5}$ Decision and Information Sciences Division, Argonne National Laboratory, USA \\ ${ }^{6}$ Department of Chemistry and Biochemistry, and Cooperative Institute for Research in the Environmental Sciences (CIRES), \\ University of Colorado, USA \\ ${ }^{7}$ Climate Change Research Center/EOS, University of New Hampshire, USA \\ ${ }^{8}$ School of Earth and Atmospheric Sciences, Georgia Institute of Technology, USA \\ ${ }^{9}$ Biogeochemistry Department, Max Planck Institute for Chemistry, Germany
}

Received: 11 December 2007 - Published in Atmos. Chem. Phys. Discuss.: 27 February 2008

Revised: 19 May 2008 - Accepted: 20 May 2008 - Published: 17 June 2008

\begin{abstract}
We interpret a suite of satellite, aircraft, and ground-based measurements over the North Pacific Ocean and western North America during April-May 2006 as part of the Intercontinental Chemical Transport Experiment Phase B (INTEX-B) campaign to understand the implications of long-range transport of East Asian emissions to North America. The Canadian component of INTEX-B included 33 vertical profiles from a Cessna 207 aircraft equipped with an aerosol mass spectrometer. Long-range transport of organic aerosols was insignificant, contrary to expectations. Measured sulfate plumes in the free troposphere over British Columbia exceeded $2 \mu \mathrm{g} / \mathrm{m}^{3}$. We update the global anthropogenic emission inventory in a chemical transport model (GEOS-Chem) and use it to interpret the observations. Aerosol Optical Depth (AOD) retrieved from two satellite instruments (MISR and MODIS) for 2000-2006 are analyzed with GEOS-Chem to estimate an annual growth in Chinese sulfur emissions of $6.2 \%$ and $9.6 \%$, respectively. Analysis of aircraft sulfate measurements from the NASA DC-8 over the central Pacific, the NSF C-130 over the east Pacific and the Cessna over British Columbia indicates most
\end{abstract}

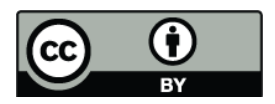

Correspondence to: A. van Donkelaar (aaron.van.donkelaar@dal.ca)
Asian sulfate over the ocean is in the lower free troposphere $(800-600 \mathrm{hPa})$, with a decrease in pressure toward land due to orographic effects. We calculate that $56 \%$ of the measured sulfate between $500-900 \mathrm{hPa}$ over British Columbia is due to East Asian sources. We find evidence of a 72$85 \%$ increase in the relative contribution of East Asian sulfate to the total burden in spring off the northwest coast of the United States since 1985. Campaign-average simulations indicate anthropogenic East Asian sulfur emissions increase mean springtime sulfate in Western Canada at the surface by $0.31 \mu \mathrm{g} / \mathrm{m}^{3}(\sim 30 \%)$ and account for $50 \%$ of the overall regional sulfate burden between 1 and $5 \mathrm{~km}$. Mean measured daily surface sulfate concentrations taken in the Vancouver area increase by $0.32 \mu \mathrm{g} / \mathrm{m}^{3}$ per $10 \%$ increase in the simulated fraction of Asian sulfate, and suggest current East Asian emissions episodically degrade local air quality by more than $1.5 \mu \mathrm{g} / \mathrm{m}^{3}$.

\section{Introduction}

The transport of Asian emissions to North America has been well documented (e.g. Parrish et al., 1992; Jaffe et al., 1999; Bertschi et al., 2004; Liang et al., 2004; Park et al., 2004). Andreae et al. (1988) measured sulfate $\left(\mathrm{SO}_{4}^{=}\right)$concentrations

Published by Copernicus Publications on behalf of the European Geosciences Union. 


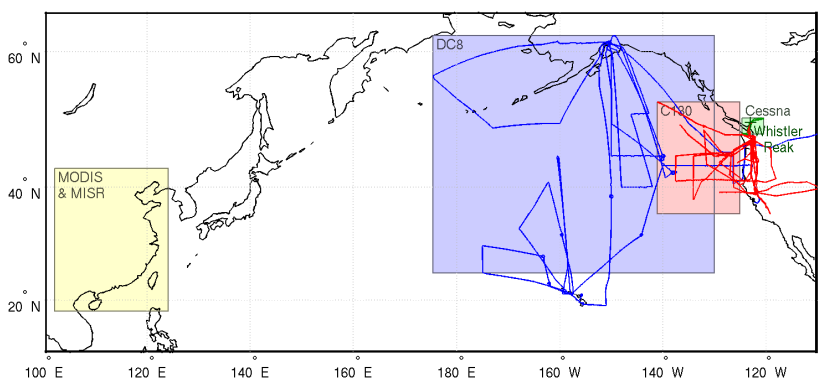

Fig. 1. Spatial domain of observations used to characterize Asian $\mathrm{SO}_{2}$ emissions and their impact. The domains and flightpaths of the DC-8, C-130 and Cessna aircraft are shown in blue, red and green, respectively. The domain of the MODIS and MISR satellite observations used to estimate emissions is shown in yellow. Figure 2 shows a detailed plot of the Cessna flight tracks.

off the northwest coast of the United States in May 1985, and attributed enhancements in the free troposphere to Asian sources. Asian emissions of sulfur oxides $\left(\mathrm{SO}_{\mathrm{x}}=\mathrm{SO}_{2}+\mathrm{SO}_{4}^{=}\right)$ are dominated by $\mathrm{SO}_{2}$ and have grown substantially over the last two decades (Streets and Waldhoff, 2000). They increasingly impact North America, affecting both regional air quality (Park et al., 2004; Heald et al., 2006) and climate (Liu et al., 2008). Additional analysis of in-situ and remote-sensed observations are needed to quantify this long-range transport and its implications.

A growing body of evidence exists for long-range transport to Canada. During the Polar Sunrise Experiment in 1992 at Alert concentrations of $\mathrm{SO}_{\mathrm{x}}$ were well correlated with long-range transport of fine anthropogenic aerosol (Barrie et al., 1994; Sirois and Barrie, 1999) analyzed aerosol composition between 1980 and 1995 to infer the presence of Eurasian $\mathrm{SO}_{4}^{=}$in the Canadian Arctic. Asian pesticides have been observed in the Yukon Territory as a result of transpacific flow (Bailey et al., 2000). The influence of long-range transport to Canada is not limited to remote regions, and is especially relevant in populated areas. Asian pesticides have been transported to the Fraser Valley, British Columbia (Harner et al., 2005). Chinese dust has been observed in British Columbia's Lower Fraser Valley (McKendry et al., 2001) and can be linked to $\mathrm{SO}_{4}^{=}$transport through the uptake of sulfur dioxide $\left(\mathrm{SO}_{2}\right)$ on dust (Jordan et al., 2003; Song et al., 2007). Dust transport to western Canada has also been observed from as far as the Sahara Desert (McKendry et al., 2007). Although aerosol in the Asian boundary layer may be readily scavenged near its source by wet deposition, $\mathrm{SO}_{2}$ emissions can escape to the free troposphere prior to $\mathrm{SO}_{4}^{=}$conversion and be subsequently transported across the Pacific Ocean (Brock et al., 2004; Dunlea et al., 2008 ${ }^{1}$ ). Elevated aerosol concentrations, attributed to East Asian combustion sources, have

\footnotetext{
${ }^{1}$ Dunlea, E., DeCarlo, P. F., Kimmel, J. R., Aiken, A. C., Peltier, R., Weber, R., Tomlison, J., Collins, D., Shinozuka, Y., Howell, S., Clarke, A., Emmons, L., Apel, E., Pfister, G., van Donkelaar,
}

been observed reaching North America near the Canadian border at Cheeka Peak (Jaffe et al., 1999).

Satellite observations offer a top-down constraint on emissions. Previous work includes absolute emissions of nitrogen oxides (Leue et al., 2001; Martin et al., 2003a; Jaeglé et al., 2005; Müller and Stavrakou, 2005), volatile organic compounds (Palmer et al., 2003; Fu et al., 2007), and carbon monoxide (Arellano et al., 2004; Heald et al., 2004; Pétron et al., 2004), as well as trends in nitrogen oxide (Richter et al., 2005; van der A et al., 2006; Zhang et al., 2007) emissions. The clearest signals in current $\mathrm{SO}_{2}$ retrievals are of volcanic activity (Khokar et al., 2005), although anthropogenic activity has also been detected (Eisinger and Burrows, 1998; Krotkov et al., 2006; Carn et al., 2007). In some regions satellite-retrieved Aerosol Optical Depth (AOD) is closely related to $\mathrm{SO}_{2}$ emissions through production of $\mathrm{SO}_{4}^{=}$(Massie et al., 2004; Dubovik et al., 2008).

Springtime weather patterns generally produce the strongest seasonal outflow from Asia (Jacob et al., 2003; Liu et al., 2005), and can result in a pronounced influence of Asian emissions upon the North American continent. During April and May 2006, the Intercontinental Chemical Transport Experiment, Phase B (INTEX-B) set out to assess this influence using a combination of aircraft and satellite measurements throughout the northeastern Pacific (Singh et al., $2008^{2}$ ). This NASA-driven initiative constituted the second half of the INTEX project, and was designed to improve the understanding of gas and aerosol transformation and transport on transcontinental and intercontinental scales.

In this paper we investigate the long-range transport of East Asian $\mathrm{SO}_{4}^{=}$to Canada. Section 2 presents the aircraft component of the Canadian contribution to INTEX-B and outlines the other instruments, platforms and the model used in this study. In Sect. 3, we estimate the recent growth in East Asian $\mathrm{SO}_{\mathrm{x}}$ emissions based upon remote sensing measurements. Section 4 combines data from a chemical transport model with in-situ measurements to characterize the Asian sulfur transport to Canada during INTEX-B. This section goes on to assess the development of East Asian $\mathrm{SO}_{4}^{=}$influx to North America between 1985 and INTEX-B using aircraft data from both periods. A case study of an Asian plume is presented in Sect. 5, along with the implications for Canadian air quality. Conclusions are in Sect. 6.

A., Millet, D., Heald, C., and Jimenez, J.-L.: Evolution of Asian aerosols during transpacific transport in INTEX-B, Atmos. Chem. Phys. Discuss., in preparation, 2008.

${ }^{2}$ Singh, H. B., Brune, W. H., Crawford, J. H., Jacob, D. J., Russel, P. B., et al.: An overview of the INTEX-B campaign: Transport and transformation of pollutants over the Pacific and the Gulf of Mexico, Atmos. Chem. Phys. Discuss., in preparation, 2008. 


\section{INTEX-B platforms}

Here we introduce the aircraft, surface and satellite measurements, and the model used for interpretation.

\subsection{In-situ measurements}

Figure 1 provides an overview of the measurement platforms and regions examined throughout this manuscript. Several aircraft participated in INTEX-B, including the NASA DC8, the NSF C-130 and a Canadian Cessna 207 described below. Throughout this manuscript, we limit the DC-8 and C130 measurements to within the boxed regions of Fig. 1 to focus on long-range transport of Asian aerosol to Canada. The DC-8 aircraft utilized both a mist chamber (Cofer et al., 1985) and bulk aerosol filters to characterize the $\mathrm{SO}_{4}^{=}$ aerosol load, during 10 flights between 17 April 2006 and 15 May 2006. The size cutoff of the onboard mist chamber system is $\sim 1 \mu \mathrm{m}$ (based on estimated particle transmission efficiency through the inlet and sampler) while that of the bulk aerosol filters has been empirically determined to be $\sim 4.5 \mu \mathrm{m}$ (McNaughton et al., 2007). Mist chamber sampling periods are less than two minutes and aerosol filters are not exposed longer than 10 to $20 \mathrm{~min}$, depending upon altitude. Uncertainties in the reported $\mathrm{SO}_{4}^{=}$mixing ratios are $\sim 20 \%$ from the mist chamber and $\sim 25 \mathrm{pptv}\left(\sim 110 \mathrm{ng} / \mathrm{m}^{3}\right)$ from the filters. A chemical ionization mass spectrometer (CIMS) instrument (Huey et al., 2004; Kim et al., 2007) was also onboard the DC-8 and used for the measurement of $\mathrm{SO}_{2}$ with a sampling frequency of approximately $3 \mathrm{~s}$.

The C-130 platform included a high-resolution time-offlight aerosol mass spectrometer (HR-ToF-AMS) (DeCarlo et al., 2006; Canagaratna et al., 2007; Dunlea et al., 2008 ${ }^{1}$ ) with $\sim 12 \mathrm{~s}$ sampling frequency and a particle-into-liquid sampler (PILS) (Weber et al., 2001; Peltier et al., 2008) of one minute sampling frequency during its 11 flights between 21 April 2006 and 15 May 2006. AMS particle transmission is approximately $\mathrm{PM}_{1}$ in vacuum aerodynamic diameter (Jayne et al., 2000) with particle transmission efficiency rapidly decreasing for aerosols larger than $0.7 \mu \mathrm{m}$ (e.g. Rupakheti et al., 2005; Liu et al., 2007). A collection efficiency (CE) of 0.5 is used for the AMS on the C-130 and is based on many previous intercomparisons (Canagaratna et al., 2007, and references therein), with a correction for increased CE under high acidity conditions (Quinn et al., 2006) as discussed by Dunlea et al. (2008) ${ }^{1}$. PILS measurements were restricted to particles less than $1 \mu \mathrm{m}$ (at $1 \mathrm{~atm}$. pressure) aerodynamic diameter via a single-stage micro-orifice impactor (Model 100, MSP Corp.). AMS and PILS sulfate measurement uncertainties are estimated at $25 \%$ and $10 \%$, respectively.

Whistler Peak Station $\left(50.1^{\circ} \mathrm{N}, 122.9^{\circ} \mathrm{W}, 2182 \mathrm{~m}\right)$ is operated by Environment Canada and has provided continuous measurements of meteorological data, $\mathrm{CO}$ and $\mathrm{O}_{3}$ since its establishment in 2002 (Macdonald et al., 2006). Inorganic filter packs of $\mathrm{SO}_{4}^{=}, \mathrm{NO}_{3}^{-}$and $\mathrm{Ca}^{+}$are also routinely collected and analyzed. In addition to these regular measurements, a HR-ToF-AMS (Zhang et al., 2008 ${ }^{3}$ ) and a MicroOrifice Uniform Deposit Impactor (MOUDI) were operated at the site for the duration of INTEX-B. The MOUDI was operated with three stages to isolate particles into three nominal size bins of $<1 \mu \mathrm{m}, 1-3 \mu \mathrm{m}$ and $>3 \mu \mathrm{m}$.

A Cessna 207 aircraft, supplied by Environment Canada during INTEX-B, contained a suite of instruments designed to capture both trace gases and aerosol pollutants (Leaitch et al., $2008^{4}$ ). Aerosol instrumentation included number concentrations of ultra-fine aerosol (PMS7610), aerosol size distribution (FSSP300: $<18 \mu \mathrm{m}$ and PCASP: $<2.5 \mu \mathrm{m}$ ) and aerosol composition by way of a quadrupole aerosol mass spectrometer (Q-AMS) (Rupakheti et al., 2005; Jimenez et al., 2003; Jayne et al., 2000). The Q-AMS detection limits are $40 \mathrm{ng} / \mathrm{m}^{3}$ for $\mathrm{SO}_{4}^{=}$and nitrate, and $600 \mathrm{ng} / \mathrm{m}^{3}$ for organic aerosol for each one-minute average measurement. The CE used with the Cessna AMS is discussed by Leaitch et al. (2008) ${ }^{4}$. Walker et al. (2008) $)^{5}$ describe and interpret $\mathrm{O}_{3}$ and $\mathrm{CO}$ measurements on the Cessna.

All Cessna 207 flights, shown in Fig. 2, originated outside Pemberton, B.C., $35 \mathrm{~km}$ north of Whistler, with the exception of one inter-comparison flight with the C-130, conducted on 9 May 2006 along the Canada-US border and related transit. Most Cessna flight tracks consisted of an ascent and descent near Whistler Peak Station before returning to the takeoff site. Thirty-three flights occurred between 22 April 2006 and 17 May 2006, with most extending from the surface to approximately $5 \mathrm{~km}(550 \mathrm{hPa})$ altitude and those with valid Q-AMS data occurring mid-late morning to late afternoon. Q-AMS data from the May 9 inter-comparison and several other flights were lost due to radio frequency interference, resulting in a total of 21 flights with successful Q-AMS measurements.

The right panel of Fig. 2 shows the flight paths for the 3 May inter-comparison flight between the Cessna and the $\mathrm{C}-130$. The inter-comparison zone is outlined in grey. The Cessna descent was not completed within the comparison region until approximately $50 \mathrm{~min}$ after the $\mathrm{C}$ - 130 had left the inter-comparison zone. To minimize the effect of sampling

\footnotetext{
${ }^{3}$ Zhang, Q., Sun, Y., Leaitch, R. W., Macdonald, A. M., Hayden, K., Li, S.-M., Liggio, J., van Donkelaar, A., Martin, R. V., Worsnop, D., Dunlea, E., Cubison, M.: Characterization of submicron aerosols at the Whistler summit during INTEX-B using an Aerodyne high-resolution time-of-flight aerosol mass spectrometer, J. Geophys. Res., in preparation, 2008.

${ }^{4}$ Leaitch, W. R., Macdonald, A. M., Anlauf, K. G. et al.: Vertical profiles of aerosols and ozone at Whistler, B.C. during INTEX-B, in preparation, 2008.

${ }^{5}$ Walker, T. W., Martin, R. V., van Donkelaar, A., Leaitch, W. R., MacDonald, A. M., Anlauf, K., Cohen, C., Huey, G. Avery, M. A., Weinheimer, A., Flocke, F., Tarasick, D., Thompson, A., Streets, D., Ziemke, J., and Buscela, E.: Trans-Pacific transport of ozone and reactive nitrogen in spring, in preparation, 2008.
} 

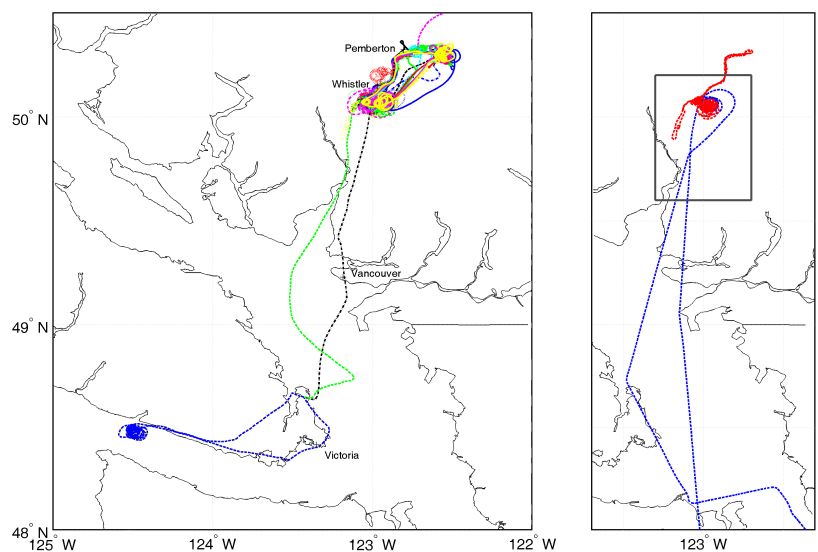

Fig. 2. Flight paths of the Cessna 207 aircraft during the INTEXB campaign over 22 April 2006 to 17 May 2006. The left panel shows all Cessna 207 flights, with colors representing individual flights. The right panel highlights the 3 May 2006 inter-comparison flight between the Cessna and C-130 aircraft. The flight track of the Cessna is shown in red, and of the C-130 in blue. The grey box defines the inter-comparison region.

time differences, we compare only measurements taken during the Cessna upward spiral against those from the C-130.

Figure 3 shows the speciated aerosol profiles from both aircraft during this intercomparison. All measurements are converted to concentrations at standard temperature and pressure of $1013 \mathrm{hPa}$ and $0^{\circ} \mathrm{C}$. Significant agreement is found between the AMS measurements, with respective Root Mean Square Differences (RMSD) and mean bias of, 0.9 and $0.3 \mu \mathrm{g} / \mathrm{m}^{3}$ for $\mathrm{SO}_{4}^{=}, 0.3$ and $0.2 \mu \mathrm{g} / \mathrm{m}^{3}$ for organics, 0.03 and $0.003 \mu \mathrm{g} / \mathrm{m}^{3}$ for nitrate, and 0.2 and $-0.0007 \mu \mathrm{g} / \mathrm{m}^{3}$ for ammonium. The largest disagreement is found in $\mathrm{SO}_{4}^{=}$at approximately $625 \mathrm{hPa}$, likely representative of a change in air mass, as indicated by significant and abnormal disagreement $(\sim 30 \%)$ between the relative humidity measurements on the two aircraft. Measurements at this particular pressure were sampled $\sim 35$ minutes apart. Removal of points between 600 and $650 \mathrm{hPa}$, decreases the RMSD and bias in $\mathrm{SO}_{4}^{=}$to 0.6 and $-0.01 \mu \mathrm{g} / \mathrm{m}^{3}$ respectively, leaving other species largely unchanged. This is considered good agreement for these sampling conditions.

MOUDI measurements of the $\mathrm{SO}_{4}^{=}$size distribution at Whistler Peak during INTEX-B indicate a mean ratio of total $\mathrm{SO}_{4}^{=}$aerosol to $\mathrm{SO}_{4}^{=}$below $1 \mu \mathrm{m}$ in aerodynamic diameter of 1.4. This value is likely more appropriate for lower tropospheric $\mathrm{SO}_{4}^{=}$, which is the focus of this study, than for upper tropospheric $\mathrm{SO}_{4}^{=}$. We scale the submicron $\mathrm{SO}_{4}^{=}$measurements by this correction factor, which is further justified in Sect. 4, to better represent total $\mathrm{SO}_{4}^{=}$mass. Airborne measurements off the west coast of Washington State and Oregon in May 1985 found that up to half of the non-seasalt $\mathrm{SO}_{4}^{=}$mass was above $1.5 \mu \mathrm{m}$ (Andreae et al., 1988) suggesting either the use of a larger scale factor may be appropriate,
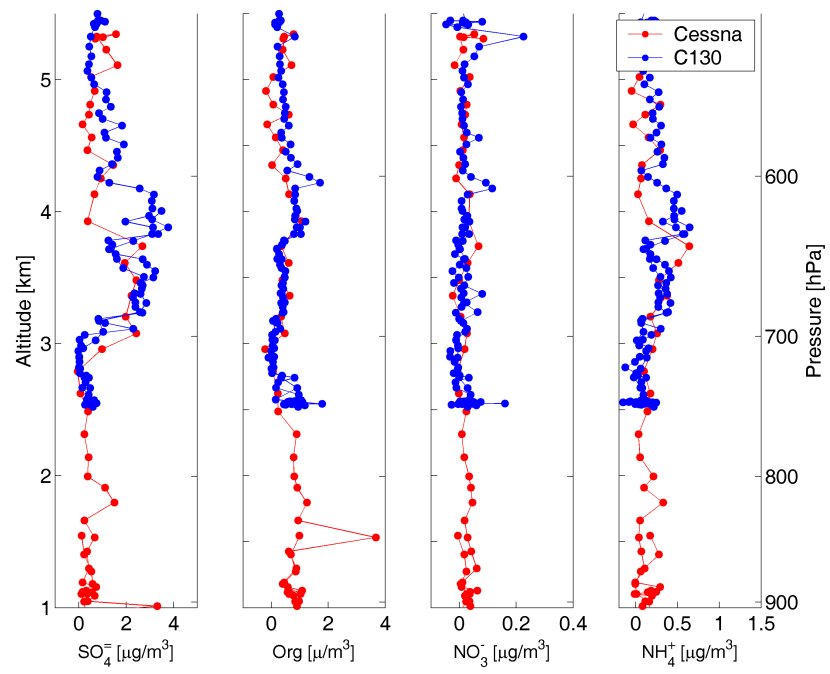

Fig. 3. Aerosol Mass Spectrometer (AMS) measurements from the May 3, 2006 inter-comparison flight over Whistler Peak Station $\left(50.1^{\circ} \mathrm{N}, 122.9^{\circ} \mathrm{W}\right)$. Cessna data are shown in red. C-130 data are shown in blue. All data at STP. No scaling for the upper size cut of the AMS has been applied to these data.

or that a change in the $\mathrm{SO}_{4}^{=}$size distribution has occurred between these flight periods. MOUDI measurements of the $\mathrm{NO}_{3}^{-}$size distribution indicate that total $\mathrm{NO}_{3}^{-}$aerosol is eight times larger than submicron $\mathrm{NO}_{3}^{-}$. However, we do not apply a correction factor to nitrate measurements due to concerns about such a large scale factor.

Figure 4 shows average vertical profiles of Cessna Q-AMS and water $\left(\mathrm{H}_{2} \mathrm{O}\right)$ concentration data obtained during four separate enhancement periods. $\mathrm{SO}_{4}^{=}$concentrations of $1-$ $3 \mu \mathrm{g} / \mathrm{m}^{3}$ dominate in the free troposphere and tend to increase with altitude, implying long-range transport. In contrast, organic concentrations typically decrease with altitude and dominate at the surface, implying a local source. These opposing trends suggest that the amount of organics transported with $\mathrm{SO}_{4}^{=}$is small and that long-range transport of organic aerosols is not a significant contributor to the organic concentration in the region studied. Leaitch et al. (2008) ${ }^{4}$ find a high level of mass closure with Cessna Q-AMS measurements, suggesting that the relatively high Q-AMS detection limit for organics $\left(0.4-0.6 \mu \mathrm{g} / \mathrm{m}^{3}\right)$ has not impacted this conclusion. They also show that the occurrence of increased sulfate usually accompanies an increase in the number and mass concentrations of coarse particles. Dunlea et al. (2008) ${ }^{1}$ find that $\mathrm{SO}_{4}^{=}$concentrations exceed those of organics for all Asian plume intercepts in the $\mathrm{C}$-130, with older air masses being characterized by a larger $\mathrm{SO}_{4}^{=}$/organics ratio than younger ones having undergone more rapid transport, presumably due to additional production of $\mathrm{SO}_{4}^{=}$during their extended transport time. The organic enhancement over 15 May-17 May is likely fuelled by an unusually high mixed layer depth, as indicated by the water concentration 
profile, and can be attributed to local sources. This period is further examined by Zhang et al. (2008) ${ }^{3}$ and McKendry et al. (2008). The contribution of nitrate to particulate mass is relatively insignificant, in part reflecting AMS size restrictions. We focus on long-range transport of $\mathrm{SO}_{4}^{=}$for the remainder of the manuscript.

\subsection{Model Description}

We use the GEOS-Chem chemical transport model v7-0409 (Bey et al., 2001) (http://www-as.harvard.edu/chemistry/ trop/geos/index.html) to interpret the aforementioned measurements. GEOS-Chem is driven by assimilated meteorological data from the Goddard Earth Observing System (GEOS-4) at the NASA Global Modeling Assimilation Office (GMAO), with 30 vertical levels and degraded to the model's horizontal resolution of $2^{\circ}$ latitude by $2.5^{\circ}$ longitude.

The aerosol simulation in GEOS-Chem includes the sulfate-nitrate-ammonium system (Park et al., 2004; Park et al., 2006), carbonaceous aerosols (Park et al., 2003; Liao et al., 2007), mineral dust (Fairlie et al., 2007) and sea-salt (Alexander et al., 2005). The aerosol and oxidant simulations are coupled through formation of sulfate and nitrate (Park et al., 2004), heterogeneous chemistry (Jacob, 2000) and aerosol effects on photolysis rates (Martin et al., 2003b). Wet and dry deposition are based upon Liu et al. (2001), including both washout and rainout. GEOS-Chem captures both the timing and distribution of Asian dust outbreaks during TRACE-P and ACE-Asia (Fairlie et al., 2007). It exhibits no significant bias in Asian $\mathrm{SO}_{\mathrm{x}}\left(\mathrm{SO}_{2}+\mathrm{SO}_{4}^{=}\right)$outflow during spring 2001 as part of the TRACE-P campaign (Park et al., 2005), although modeled $\mathrm{SO}_{4}^{=}$concentrations were $50 \%$ high during ACE-Asia, which may suggest an error in $\mathrm{SO}_{2}$ oxidation rates (Heald et al., 2005).

The global emission inventory in the standard GEOSChem model is based on GEIA (Benkovitz et al., 1996) for the base year of 1985 with scale factors to 1998 . We implement here the EDGAR 3.2FT2000 emission inventory based upon the year 2000 (Olivier et al., 2001) to provide a more current estimate of global emissions of $\mathrm{NO}_{\mathrm{x}}, \mathrm{SO}_{\mathrm{x}}$ and $\mathrm{CO}$. The global inventory is replaced by regional inventories from NEI99 (http://www.epa.gov/ $\mathrm{ttn} / \mathrm{chief} /$ net/1999inventory.html) over the United States for 1999, BRAVO (Kuhns et al., 2005) over Mexico for 1999 and Streets et al. $(2003,2006)$ for $2000\left(\mathrm{NO}_{\mathrm{x}}\right.$ and $\left.\mathrm{SO}_{\mathrm{x}}\right)$ and 2001 (CO) for eastern Asia. EMEP emissions (http://www.emep. int) of $\mathrm{NO}_{\mathrm{x}}$ and $\mathrm{CO}$ are used over Europe for up to 2000. We update the eastern Asia emissions to 2006 from Streets et al. (http://www.cgrer.uiowa.edu/EMISSION_DATA_new/ index_16.html and implement CAC emissions (http://www. ec.gc.ca/pdb/cac/) over Canada for 2005 and EMEP $\mathrm{SO}_{\mathrm{x}}$ emissions (Vestreng et al., 2007) over Europe for the year 2004.

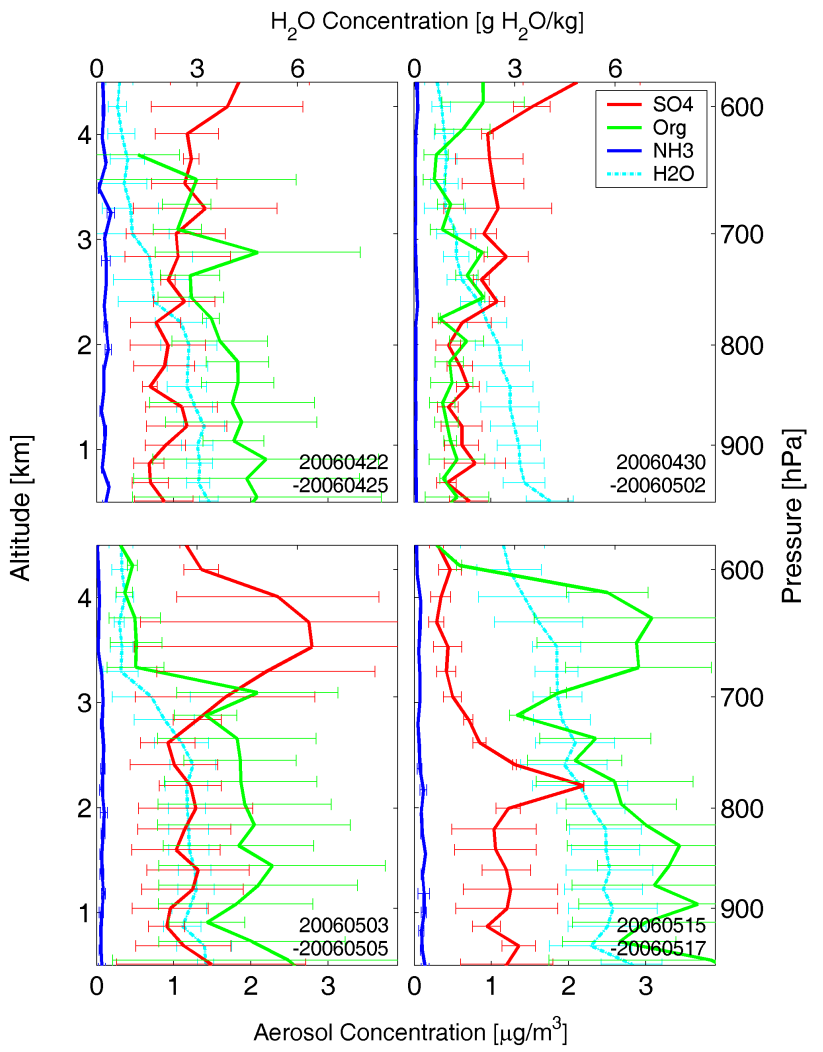

Fig. 4. Cessna Q-AMS vertical profiles of sulfate, organics and nitrate during four enhancement periods. Sulfate $\left(\mathrm{SO}_{4}^{\overline{ }}\right)$ data have been scaled by multiplying with a factor of 1.4 to account for particle size restrictions as inferred from MOUDI measurements at Whistler summit. Aerosol data are at STP. Water $\left(\mathrm{H}_{2} \mathrm{O}\right)$ concentration profiles are in cyan. Date ranges are indicated in the bottom right of each plot. Error bars represent one standard deviation of the data. A small vertical offset is included between datasets for visibility.

We scale all regional and global inventories from their respective base year to 2003, the last year of available statistics, unless its base year is after 2003. Our approach follows Bey et al. (2001) and Park et al. (2004). Emissions are scaled according to estimates provided by individual countries, where available. These countries/regions include the United States, Canada, Japan and Europe. $\mathrm{NO}_{\mathrm{x}}$ emissions of remaining countries are scaled proportional to changes in total $\mathrm{CO}_{2}$ emissions. $\mathrm{SO}_{\mathrm{x}}$ emissions are similarly scaled to solid fuel $\mathrm{CO}_{2}$ emissions and $\mathrm{CO}$ emissions to liquid fuel $\mathrm{CO}_{2}$ emissions. A scale factor of $4.1 \%$ per year is used for ship emissions (Corbett et al., 2007). $\mathrm{CO}_{2}$ emission data are obtained from the Carbon Dioxide Information Analysis Center (CDIAC).

In addition to annual scale factors, diurnal scale factors are also applied to $\mathrm{NO}_{\mathrm{x}}$ emissions. Here, the intra-day variation of each grid cell is based upon the diurnal variation of each source type, as provided with the EDGAR inventory, and its relative contribution to total $\mathrm{NO}_{\mathrm{x}}$ emissions within that cell. 

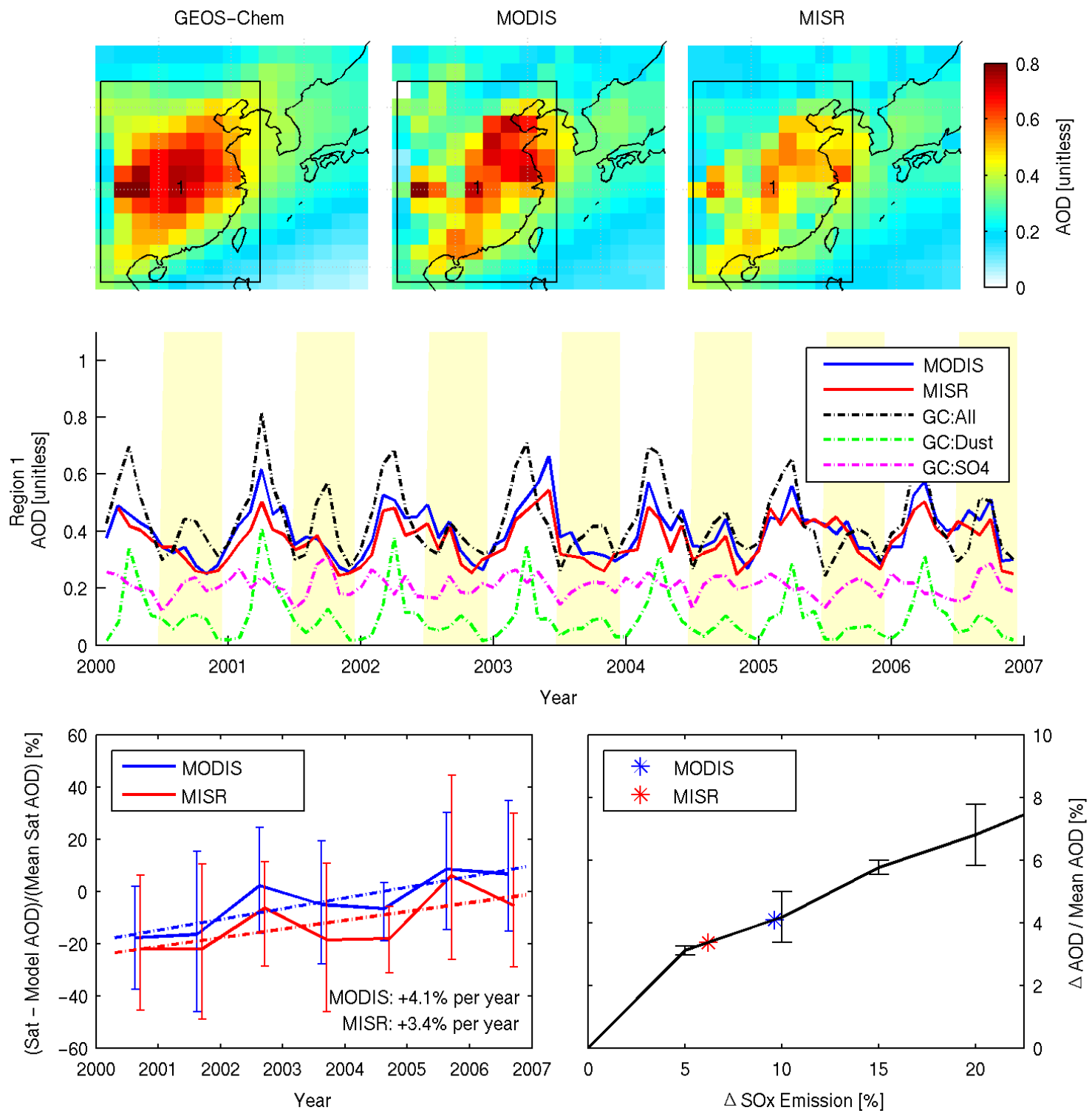

Fig. 5. Aerosol Optical Depth (AOD) from the MODIS and MISR satellite instruments and a GEOS-Chem simulation. The top row shows mean AOD over 2000-2006 and defines Region 1 as used in the lower panels. The middle panel shows monthly mean retrieved and simulated AOD for Region 1 with simulated $\mathrm{SO}_{\mathrm{x}}$ emissions held at 2000 levels. Simulated contributions of dust and $\mathrm{SO}_{4}^{=}$to total AOD are also shown. Highlighted areas indicate time periods used in the lower panels. The bottom left panel shows the Region 1 difference between retrieved and simulated AOD averaged between July and December of each year expressed as a percentage of mean retrieved AOD. Dashed line indicates best linear fit, error bars represent the 20th and 80th percentile. The bottom right panel shows the simulated relationship in Region 1 between total AOD and $\mathrm{SO}_{\mathrm{x}}$ emissions over July-December 2000-2006 as calculated with 5 simulations with $\mathrm{SO}_{\mathrm{x}}$ emissions increased by $0 \%$, 5\%, $10 \%, 15 \%$ and $20 \%$. The red and blue stars respectively indicate the observed change in difference of simulated AOD between MISR and MODIS. Error bars denote one standard deviation of the data.

\subsection{Satellite instrumentation}

Aerosol Optical Depth (AOD), a measure of light extinction, has been retrieved since 2000 from the Moderate Resolution Imaging Spectroradiometer (MODIS) and Multi-angle Imaging Spectroradiometer (MISR), onboard the NASA satellite Terra. The MODIS retrieval of AOD is based on scene brightness over dark surfaces, using empirical relationships in the spectral variation in surface reflectivity (Kaufmann et al., 1997; Remer et al., 2005). We use the MODIS collection 5 dataset (Levy et al., 2007). The MISR algorithm uses observed differences in the spatial variation of backscattered radiation with changing viewing angle to self-consistently retrieve surface reflectivity and AOD (Martonchik et al., 2002; 
Kahn et al., 2005). Global coverage in the absence of clouds is achieved daily from MODIS and in 6 to 9 days from MISR.

\section{Estimate of sulfur emission growth from China}

Significant increases in AOD retrieved from the Total Ozone Mapping Spectrometer (TOMS) over China between 19792000 and the Advanced Very High Resolution Radiometer (AVHRR) off the east coast of China between the periods 1988-1991 and 2002-2005 are attributed to increased aerosol sources (Massie et al., 2004; Mishchenko and Geogdzhayer, 2007). Here we investigate recent retrievals of AOD from MODIS and MISR and assess their relationship with Chinese sulfur emissions growth. We first use GEOSChem, with East Asian anthropogenic emissions held at year 2000 levels, to investigate meteorologically induced changes to AOD.

The top row of Fig. 5 shows mean AOD for 2000-2006 over East Asia from MODIS, MISR and GEOS-Chem. Simulated AOD includes all major aerosol types (mineral dust, sulfate-nitrate-ammonium, carbonaceous, and sea-salt). A region of pronounced enhancement, designated as Region 1, is apparent in all three datasets. MODIS AOD exceeds MISR AOD by $12 \%$ over this region, consistent with comparisons by Abdou et al. (2005). Simulated AOD exceeds MISR AOD by $22 \%$ and exhibits a smoother distribution than both retrievals, with a more centralized maximum that reflects the temporally static emissions used. The middle panel of Fig. 5 presents monthly average AOD within the Region 1. All three datasets contain a distinct seasonal variation with a spring maximum and a fall minimum that reflects the seasonal variation in dust as noted by Prospero et al. (2002). Simulated AOD generally captures the retrieved monthly variation and magnitude as compared to both instruments (MODIS: $r^{2}=0.46$, RMSD $=0.09$; MISR: $r^{2}=0.36$, $\mathrm{RMSD}=0.12$ ), although the simulation tends to overestimate springtime AOD. Simulated AOD contributions from dust (green) and $\mathrm{SO}_{4}^{=}$(magenta) indicate that dust comprises the largest fraction of springtime $\mathrm{AOD}$, whereas $\mathrm{SO}_{4}^{=}$dominates during other periods. We focus on the periods between July and December, as indicated by yellow bars, when an average $56 \%$ of total AOD results from the presence of $\mathrm{SO}_{4}^{=}$, compared to $17 \%$ from dust.

The bottom left panel of Fig. 5 shows the annual mean difference over July-December between simulated and retrieved AOD for Region 1, expressed as a percentage of the mean retrieved AOD from each instrument over the six-year, low-dust period. We find a significant trend in the satellite-model AOD difference for both MODIS $\left(+4.1 \% /\right.$ year, $\left.r^{2}=0.72\right)$ and MISR $\left(+3.4 \% /\right.$ year, $\left.r^{2}=0.54\right)$. We associate this trend with increased $\mathrm{SO}_{\mathrm{x}}$ emissions, as $\mathrm{SO}_{4}^{=}$dominates simulated AOD in this comparison, simulated $\mathrm{SO}_{\mathrm{x}}$ emissions are held at 2000 levels and interannual changes of non-anthropogenic aerosols, such as dust and sea salt, are accounted for in the simulation. Trends in other aerosols could play a role, but would be less apparent due to their smaller AOD over this region during July-December.

The quantitative relationship between $\mathrm{AOD}$ and $\mathrm{SO}_{2}$ emissions depends on a number of factors including $\mathrm{SO}_{2}$ oxidation rates, dynamics and aerosol deposition (Dubovik et al., 2008). We quantify the relationship by conducting sensitivity simulations with increased $\mathrm{SO}_{\mathrm{x}}$ emissions, and examining the change in simulated AOD. The bottom right panel of Fig. 5 shows the calculated relationship between $\mathrm{SO}_{\mathrm{x}}$ emissions and AOD over Region 1. The calculated ratio of $\Delta \mathrm{AOD} \% / \Delta \mathrm{SO}_{\mathrm{x}}$ emissions $\%$ is nearly linear over this region during July to December. The annual trends in the difference between simulated and retrieved AOD correspond to simulations with an annual growth in $\mathrm{SO}_{\mathrm{x}}$ emissions of $6.2 \% / \mathrm{yr}$ for MISR and 9.6\%/yr for MODIS. In general agreement, a comparison of the two bottom-up $\mathrm{SO}_{\mathrm{x}}$ emission inventories for 2000 (Streets et al., 2003) and 2006 (http://www.cgrer. uiowa.edu/EMISSION_DATA_new/index_16.html) over Region 1 yields an annual growth of $9.9 \%$. Beyond actual emission growth, changes between the 2000 and 2006 inventories include the addition of local inventories not present in, and improvement and corrections made to, the original 2000 inventory. These factors may account for the slight discrepancy between the growth estimates. We adopt the 2006 bottom-up inventory for our standard simulation, as it provides additional information on the spatial distribution of these $\mathrm{SO}_{\mathrm{x}}$ emissions.

\section{Campaign average analysis of transpacific transport}

The top row of Fig. 6 shows campaign average $\mathrm{SO}_{\mathrm{x}}$ concentrations for the DC-8 over the domain in Fig. 1. Filter pack and mist chamber measurements of $\mathrm{SO}_{4}^{=}$have been combined with corresponding CIMS $\mathrm{SO}_{2}$ measurements. Both filter pack and mist chamber based measurements show a maximum around $700 \mathrm{hPa}$. Heald et al. (2006) attribute the $\mathrm{SO}_{4}^{=}$maximum in the lower free troposphere to preferential scavenging during transport either in the boundary layer or during lifting to the upper troposphere. Our standard simulation of total $\mathrm{SO}_{\mathrm{x}}$ captures the relative vertical profile of filter pack based measurements over the domain of the DC8 , but overestimates their magnitude between $500-900 \mathrm{hPa}$ with a RMSD of $0.32 \mu \mathrm{g} / \mathrm{m}^{3}$ (mean bias $=15 \%$ ). Mist chamber $\mathrm{SO}_{4}^{=}$measurements are scaled by 1.4 to account for supermicron aerosol as described in Sect. 2.1. Over 500$900 \mathrm{hPa}$, the campaign average filter pack measurements are $33 \%$ higher than the unscaled mist chamber measurements, lending support to this scale factor. Mist chamber based $\mathrm{SO}_{\mathrm{x}}$ measurements are well captured over the same range ( $\mathrm{RMSD}=0.20 \mu \mathrm{g} / \mathrm{m}^{3}$, mean bias $=7.5 \%$ ). Direct comparison of filter pack and mist chamber $\mathrm{SO}_{4}^{=}$with simulated values show weaker agreement (Filter Pack: RMSD $=0.47 \mu \mathrm{g} / \mathrm{m}^{3}$, mean bias $=42 \%$; Mist Chamber: RMSD $=0.42 \mu \mathrm{g} / \mathrm{m}^{3}$, mean 


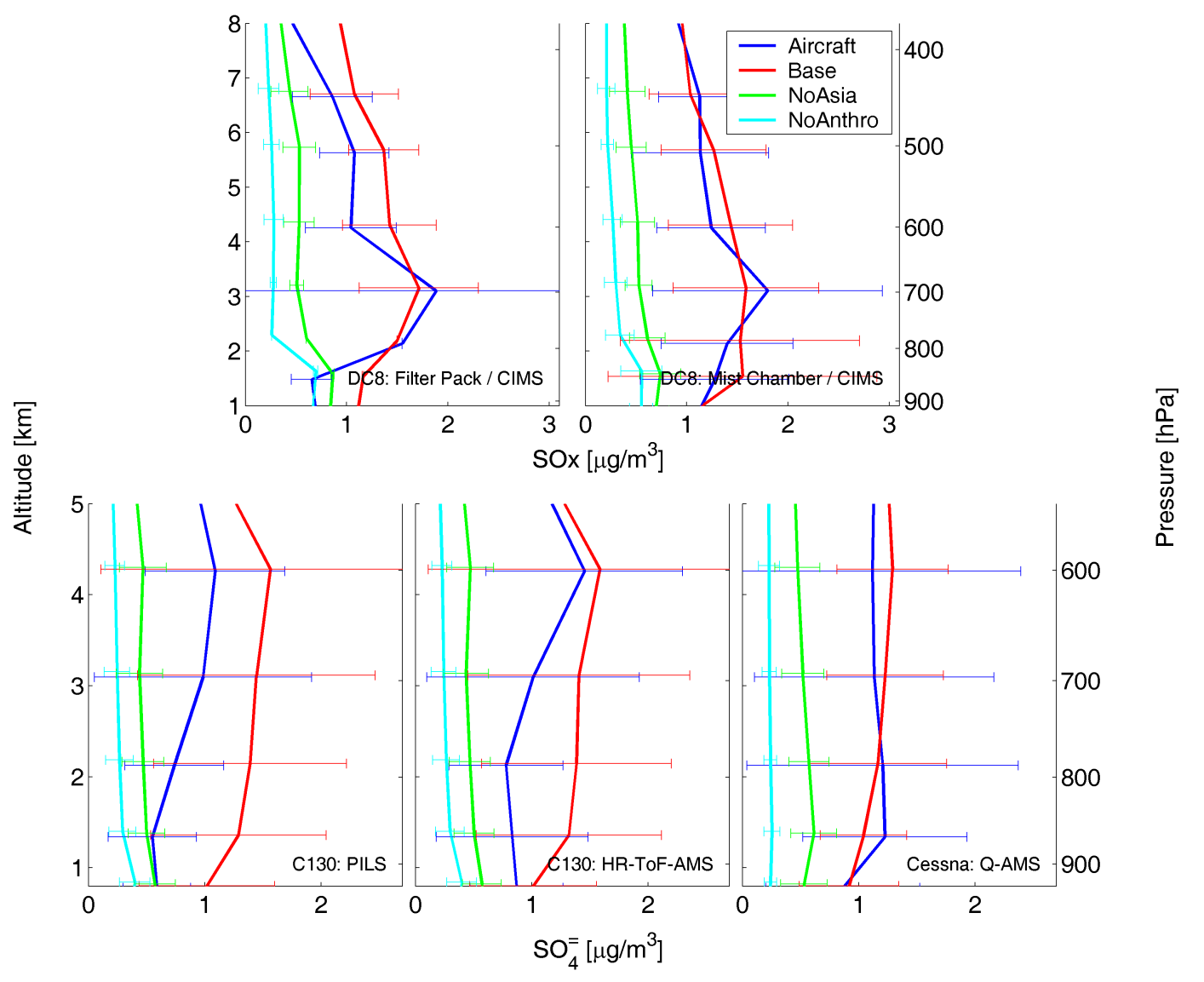

Fig. 6. Campaign average aircraft measurements of $\mathrm{SO}_{\mathrm{x}}$ and $\mathrm{SO}_{4}^{=}$during INTEX-B, within the boundaries shown in Fig. 1. Simulated cases include our standard simulation, no East Asian emissions, and no global anthropogenic emissions. All measured and modeled data are at STP. Mist Chamber, AMS and PILS SO$=$ data are increased by a factor of 1.4 to account for particle size restrictions. Error bars denote one standard deviation. A small vertical offset is included between datasets for visibility.

bias $=42 \%$ ) than for $\mathrm{SO}_{\mathrm{x}}$, likely reflecting an overestimate in the $\mathrm{SO}_{2}$ oxidation rate (Heald et al., 2005). However, the bias in $\mathrm{SO}_{4}^{=}$found here for the East Pacific is lower than found by Heald et al. (2005) for the West Pacific, suggesting a decrease with air mass age as continued $\mathrm{SO}_{4}^{=}$production during transport decreases the ratio of $\mathrm{SO}_{2}$ to $\mathrm{SO}_{\mathrm{x}}$.

The bottom panels of Fig. 6 show campaign average $\mathrm{SO}_{4}^{=}$measurements on the C-130 and Cessna, sampled coincidently in time and space with simulated concentrations. Campaign average $\mathrm{SO}_{4}^{=}$concentrations for the C-130 measurements generally increase with altitude, reaching a maximum at $600 \mathrm{hPa}$. The C-130 HR-ToF-AMS measurements consistently exceed the PILS measurements, indicative of current uncertainties in aerosol measurement technologies. During a blind intercomparison conducted 15 May 2006 during a period of DC-8 and C-130 formation flying, the DC-8 Mist Chamber and C-130 PILS sulfate were in close agreement (slope $=1.00,1$ sigma $=0.03 \mu \mathrm{g} / \mathrm{m}^{3}$, range 0.15 to $\left.1.15 \mu \mathrm{g} / \mathrm{m}^{3}, r^{2}=0.95\right)$. The $\mathrm{C}-130$ had considerable freedom to chase individual events. Despite this, simulated total $\mathrm{SO}_{4}^{=}$ between 500-900 hPa has an RMSD of $0.40 \mu \mathrm{g} / \mathrm{m}^{3}$ (mean bias $=34 \%$ ) versus $\mathrm{C}-130 \mathrm{HR}-\mathrm{ToF}-\mathrm{AMS}$ measurements and an RMSD of $0.54 \mu \mathrm{g} / \mathrm{m}^{3}$ (mean bias=59\%) versus C -130 PILS measurements. The simulation exhibits the weak enhancement at $600 \mathrm{hPa}$, although fails to represent the lower concentrations at lower altitudes.

The sampling strategy for the Cessna was to conduct frequent profiles over Whistler Peak. Such a sampling strategy facilitated comparison with simulated results, provided context for the measurements at Whistler summit, and accommodated the range and duration of the Cessna. Cessna measurements indicate a fairly uniform vertical profile, with a large standard deviation in the free troposphere that reflects an oscillation between clean conditions and plumes. The simulation agrees significantly with sizecorrection scaled measured $\mathrm{SO}_{4}^{=}\left(\mathrm{RMSD}=0.13 \mu \mathrm{g} / \mathrm{m}^{3}\right.$, mean bias $=2.5 \%$ ). While recognizing the potential influence of both measurement uncertainty and the limitation of applying a constant size-correction factor across both altitude and aircrafts, the eastward decrease in the bias between the DC- 
8 and Cessna aircraft may indicate an increasing $\mathrm{SO}_{4}^{=} / \mathrm{SO}_{\mathrm{x}}$ ratio in the measurements.

Figure 6 also shows simulations without anthropogenic East Asian and all anthropogenic sources for all three aircraft flight tracks. Anthropogenic East Asian $\mathrm{SO}_{\mathrm{x}}$ dominates throughout the DC-8 profiles, comprising $60 \%$ of the simulated mass between $500-900 \mathrm{hPa}$, with the largest contribution in the lower free troposphere. Other anthropogenic $\mathrm{SO}_{\mathrm{x}}$ sources comprise an additional $17 \%$. For the C-130 flight track, closer to North America, the sensitivity simulation attributes $67 \%$ of $\mathrm{SO}_{4}^{=}$to be of Asian origin, with a peak at $600 \mathrm{hPa}$. For the Cessna profiles over Whistler, local sources are most significant below $850 \mathrm{hPa}$, with the influence of East Asian anthropogenic emissions increasing with altitude. We calculate that $56 \%$ of the measured $\mathrm{SO}_{4}^{=}$between $500-900 \mathrm{hPa}$ is from East Asia. Model analysis indicates the influence of East Asian sources at higher altitudes in both C-130 and Cessna versus the DC- 8 measurements. This orographic effect is induced by rising air masses on approach to North American mountain ranges.

Of interest is the evolution of Asian sulfate over the last two decades. Figure 7 shows the mean non-seasalt sulfate profile observed by Andreae et al. (1988) during 4 flights in May 1985 using the NCAR King Air, covering a part of the $\mathrm{C}-130$ INTEX-B flight domain. $\mathrm{SO}_{4}^{=}$concentrations (adjusted to STP at $273 \mathrm{~K}$, sum of coarse and fine fractions) increased with altitude below $5 \mathrm{~km}$, from $0.3-0.6 \mu \mathrm{g} / \mathrm{m}^{3}$ in the marine boundary layer to $0.6-0.8 \mu \mathrm{g} / \mathrm{m}^{3}$ in the cloud convection layer and free troposphere. The 1985 measurements thus showed lower concentrations, but a similar trend with increased altitude as was seen in the C-130 measurements. Mean C-130 measurements between $500-900 \mathrm{hPa}$ are higher than the 1985 data by $60 \%$ from the PILS and by $90 \%$ from HR-ToF-AMS.

Differences in measurement techniques, flight tracks and meteorology could contribute to the apparent trend. Therefore we further interpret these observations by conducting a GEOS-Chem simulation using 1985 emissions and meteorology and sampling along the 1985 flights tracks. Global emissions for 1985 are taken from GEIA (Bentovitz et al., 1996), except for East Asia which are based on Streets et al. (2003, 2006) and scaled following Streets et al. (2000b, 2006). The simulation reproduces the measurements with an RMSD of $0.25 \mu \mathrm{g} / \mathrm{m}^{3}$ (mean bias=21\%) over 500-900 hPa. A sensitivity simulation without anthropogenic East Asian emissions reveals that this source contributes $0.14 \mu \mathrm{g} / \mathrm{m}^{3}$ (20\%) to the measured values in 1985 , significantly reduced compared to the $67 \%$ along the C-130 flights in 2006 .

To account for meteorological variation between 1985 and 2006, we also simulate the 2006 INTEX-B period using 1985 emissions. The relative contribution of East Asian $\mathrm{SO}_{4}^{=}$to the C-130 area (April-May, 34-55 $\mathrm{N}, 123.75-$ $141.25^{\circ} \mathrm{W}, 500-900 \mathrm{hPa}$ ) between 1985 and 2006 increased $72 \%$ under identical meteorological conditions. The relative contribution in the King Air (April-May, 45-49 $\mathrm{N}$,

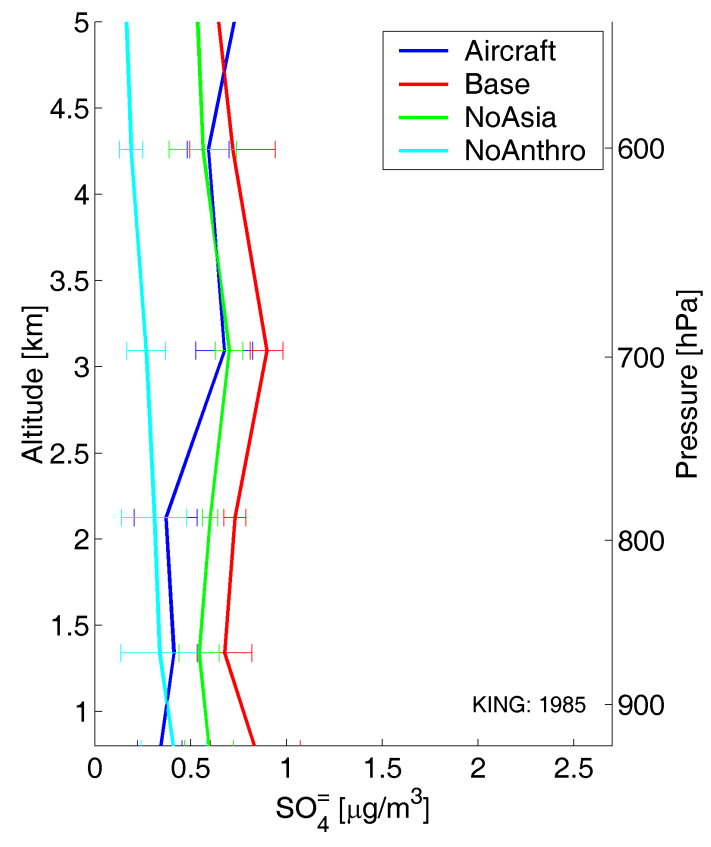

Fig. 7. Average aircraft measurements of $\mathrm{SO}_{4}^{=}$during $1985 \mathrm{King}$ Air flights, within the boundary shown in Fig. 1. Simulated cases of total $\mathrm{SO}_{4}^{=}$include our standard simulation, no East Asian emissions, and no global anthropogenic emissions. All measured and modeled data are at STP. Error bars denote one standard deviation.

123.75-126.25 $\mathrm{W}, 500-900 \mathrm{hPa}$ ) and Cessna (April-May, $49-51^{\circ} \mathrm{N}, 123.75-121.23^{\circ} \mathrm{W}, 500-900 \mathrm{hPa}$ ) flight regions increase similarly by $74 \%$ and $85 \%$, respectively.

\section{Asian plume development and influence}

Figure 8 examines the development of an Asian plume from 18 April 2006 to 25 April 2006. MODIS AOD retrievals from both the Aqua (1:30 overpass) and Terra (10:30 overpass) satellites are plotted with simulation results from the same period. The GEOS-Chem simulation successfully captures many of the features associated with the influx event, which is dominated by dust, and also carries $\mathrm{SO}_{4}^{=}$. Both retrieval and simulation show this plume beginning from China on 18 April and stretching across the Pacific Ocean through 21 April, and finally sweeping down from the north while moving eastward over the North American coast. This event is further discussed by McKendry et al. (2008).

Figure 9 shows individual Cessna and GEOS-Chem $\mathrm{SO}_{4}^{=}$ profiles taken between 22 and 25 April, during the arrival of this Asian plume. The accuracy of individual simulated profiles, shown in the left panel cluster, varies with RMSD ranging between $0.39-0.87 \mu \mathrm{g} / \mathrm{m}^{3}$. Simulations can fail to produce accurate plumes (e.g. Dunlea et al., $2008^{1}$ ), but in this case the simulated plume has been transported too quickly, with simulated concentrations exceeding measurements on 24 April, but the opposite on 25 April. During 

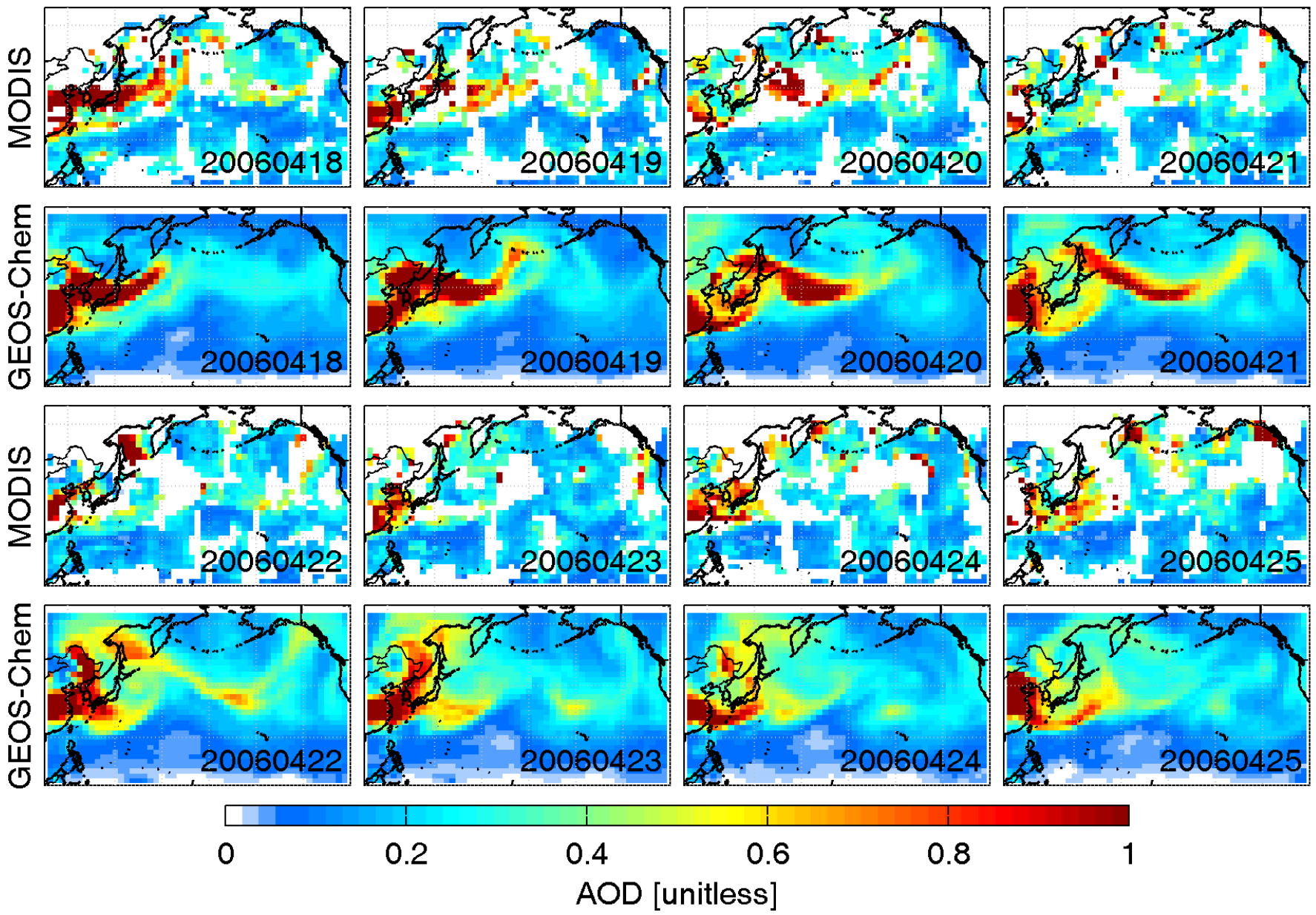

0.8

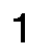

Fig. 8. The development of an Asian plume between 18-25 April 2006 as retrieved from MODIS and as simulated by GEOS-Chem. White spaces indicate regions of less than 10 cloud free scenes within a $2^{\circ} \times 2.5^{\circ}$ area.

long range transport events, small errors in the meteorological fields used by chemical transport models can compound to create offsets in time and space, making individual model profiles less representative than average comparisons. The right panel shows a mean profile comparison during this period. Significant agreement $\left(\mathrm{RMSD}=0.25 \mu \mathrm{g} / \mathrm{m}^{3}\right)$ suggests this event was well represented, despite the weaker agreement of individual profiles.

Figure 10 shows simulated average conditions during April and May 2006. The top panel shows mean concentrations at $2 \mathrm{~km}$, where DC- $8 \mathrm{SO}_{4}^{=}$enhancements were observed. Simulated $\mathrm{SO}_{4}^{=}$along the North American Pacific coast show increased concentrations relative to western continental regions. Major regional anthropogenic sources produce a large increase in $\mathrm{SO}_{4}^{=}$concentrations over eastern United States and Canada. The middle and bottom panels show vertical cross-sections of $\mathrm{SO}_{4}^{=}$and percentage of $\mathrm{SO}_{4}^{=}$ originating from East Asia, respectively, averaged between the blue lines of the top panel. The highest overall magnitude $\left(>1 \mu \mathrm{g} / \mathrm{m}^{3}\right)$ is again simulated in eastern North America and is predominately from regional emissions. Nonethe- less, a narrow band of Asian influence in excess of $40 \%$ prevails over the continent at $4.5 \mathrm{~km}$, where overall concentrations are $\sim 0.3 \mu \mathrm{g} / \mathrm{m}^{3}$. Along coastal regions, the largest East Asian influence is found between 1 and $5 \mathrm{~km}$, where $40 \%$ of the overall $\mathrm{SO}_{4}^{=}$burden originated in East Asia. Interaction with the planetary boundary layer is facilitated by a combination of plume subsidence and mountain-induced mixing processes typical of southern British Columbia (McKendry et al., 2001). We calculate that surface concentrations of $\mathrm{SO}_{4}^{=}$ along the southern Pacific Canadian coast are increased by $0.31 \mu \mathrm{g} / \mathrm{m}^{3}(\sim 30 \%)$ as a result of Asian emissions in spring. We take the mean model bias as compared to the C-130 and Cessna aircraft to estimate an error of approximately $25 \%$ in this calculation. Heald et al. (2006) found a $0.16 \mu \mathrm{g} / \mathrm{m}^{3}$ enhancement in $\mathrm{SO}_{4}^{=}$over the northwest United States during periods of Asian influence. Yu et al. (2008) used MODIS observations to access the seasonal variation in transpacific pollution aerosol and conclude that springtime transport is about twice as large as during other seasons. 

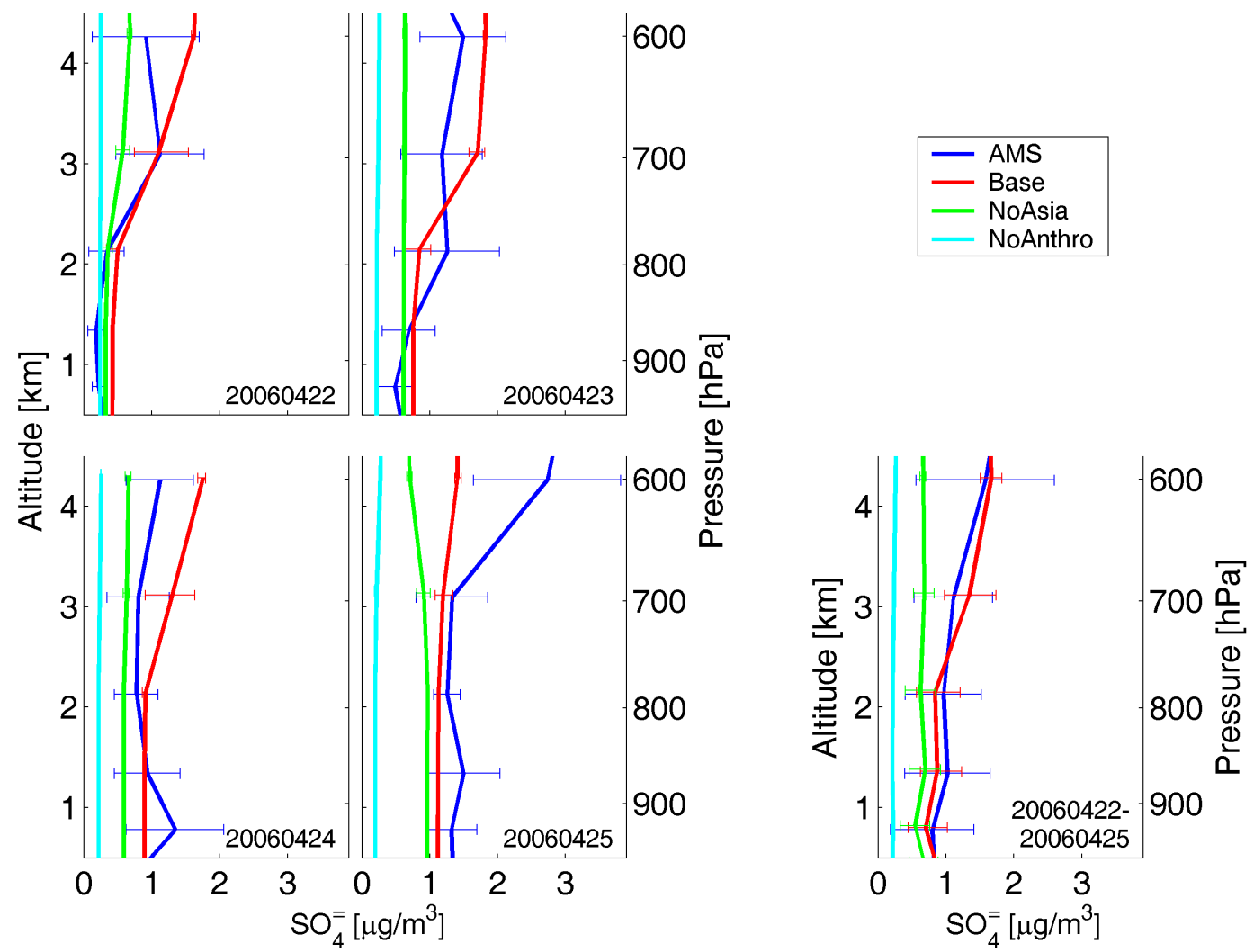

Fig. 9. Cessna Q-AMS SO $=$ profiles taken 22-25 April 2006. The left-hand panels show individual flight profiles. The right panel shows a mean profile of the same data. Error bars represent one standard deviation of the data. Q-AMS data are at STP and scaled a factor of 1.4 to account for particle size restrictions. A small vertical offset is included between the datasets for visibility.

We go on to explore the surface $\mathrm{SO}_{4}^{=}$measurements from the National Air Pollution Surveillance (NAPS) Network in the Vancouver area for evidence of Asian influence. Figure 11 shows surface $\mathrm{SO}_{4}^{=}$concentrations between April and May 2006 in the Vancouver area as a function of the modeled percent $\mathrm{SO}_{4}^{=}$originating in Asia. The two measurement sites in the Vancouver area, Abbotsford and Vancouver, reside in the same model grid box. Black circles correspond to measurement averages, binned at intervals of 5\% simulated East Asian influence. Individual measurements show substantial scatter, but linear regression of the binned measurements show a significant correlation $\left(r^{2}=0.82\right)$. Binned measurements indicate that an additional $0.32 \mu \mathrm{g} / \mathrm{m}^{3}$ reaches the surface with each $10 \%$ increase in modeled Asian $\mathrm{SO}_{4}^{=}$, corroborating that current levels of Asian sulfur emissions are impacting surface $\mathrm{SO}_{4}^{=}$concentrations in Canada. Aerosol transport events are episodic and the daily influence of East Asian $\mathrm{SO}_{4}^{=}$varies dramatically. Figure 11 suggests that during plumes East Asian $\mathrm{SO}_{4}^{=}$can contribute more than $1.5 \mu \mathrm{g} / \mathrm{m}^{3}$ to coastal western Canadian concentrations. This is of similar magnitude to enhancements observed by the Cessna Q-AMS during plume events shown in Fig. 4.

\section{Conclusions}

We interpreted a suite of satellite (MODIS and MISR), aircraft (DC-8, C-130 and Cessna 207) and ground-based measurements (Whistler Peak, NAPS) over the North Pacific Ocean and western North America in April-May 2006 as part of the INTEX-B campaign to understand the implications of long-range transport of Asian aerosol to Canada.

The Canadian component of INTEX-B included 33 flights from a Cessna 207 aircraft. We compare the Cessna quadrupole Aerodyne Mass Spectrometer (Q-AMS) measurements with a high resolution time of flight AMS (HR-ToF-AMS) onboard the C-130 during an intercomparison flight, yielding an overall bias of $-0.01 \mu \mathrm{g} / \mathrm{m}^{3}$ with appreciable scatter (RMSD $=0.6 \mu \mathrm{g} / \mathrm{m}^{3}$ ) for sulfate $\left(\mathrm{SO}_{4}^{=}\right)$and similar agreement for organics (bias $=0.2 \mu \mathrm{g} / \mathrm{m}^{3}$, $\left.\mathrm{RMSD}=0.3 \mu \mathrm{g} / \mathrm{m}^{3}\right)$. However, there was a small systematic difference $(<20 \%)$ between the C-130 HR-ToF-AMS sulfate and a co-located PILS measurement of $\mathrm{SO}_{4}^{=}$(Dunlea et al., $2008^{1}$ ). We use ground-based measurements (MOUDI) of the $\mathrm{SO}_{4}^{=}$size distribution at Whistler Peak to estimate the mass in the super-micron range and use a factor of 1.4 to compensate for this loss. Cessna profiles over Whistler, B.C. 


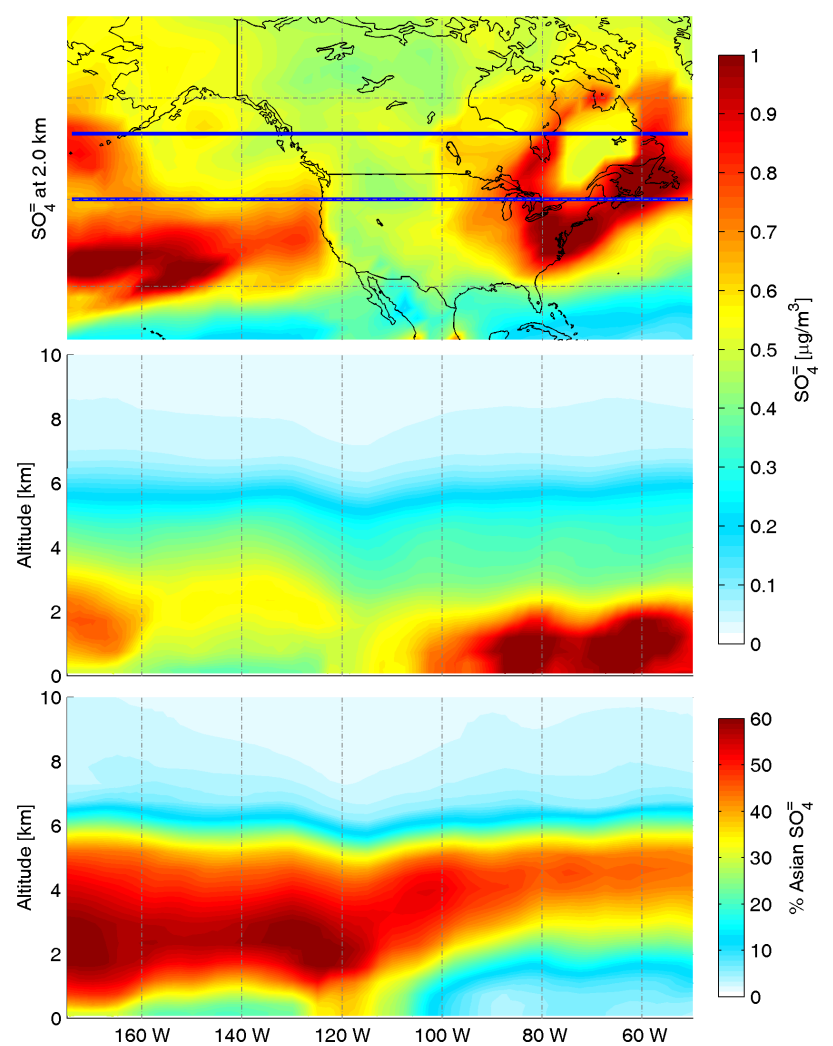

Fig. 10. Average simulated conditions for April and May 2006. The top panel shows total $\mathrm{SO}_{4}^{=}$concentrations at $\sim 2 \mathrm{~km}$ altitude. Middle and bottom panels display the mean cross-sectional total concentration and East Asian influence, respectively, between the blue lines in the top panel.

show $\mathrm{SO}_{4}^{=}$enhancements of $1-2 \mu \mathrm{g} / \mathrm{m}^{3}$ over $600-700 \mathrm{hPa}$, indicative of long-range transport, whereas organic enhancements are largest near the surface, suggesting a local emission source. We did not detect long-range transport of significant organic aerosol from the Cessna data, contrary to expectations.

We interpret these observations with a global chemical transport model, GEOS-Chem, to simulate the implications of anthropogenic activity. We implement a more recent global bottom-up inventory (EDGAR) and develop updated scale factors, bringing global anthropogenic emissions from 1998 to at least the year 2003. We also implement current bottom-up inventories for East Asia for 2006, Canada for 2005 and Europe for 2004.

Retrieved Aerosol Optical Depth (AOD) from MISR and MODIS during low dust periods (Jul-Dec) are used to evaluate the growth of $\mathrm{SO}_{\mathrm{x}}$ emissions between 2000-2006. We find a growth in the difference between simulated and retrieved AOD of 3.4\%/yr (MISR) and 4.1\%/yr (MODIS) using constant anthropogenic emissions sources as represented by GEOS-Chem. GEOS-Chem calculations of the change in AOD for a change in $\mathrm{SO}_{\mathrm{x}}$ emissions indicate a near-linear

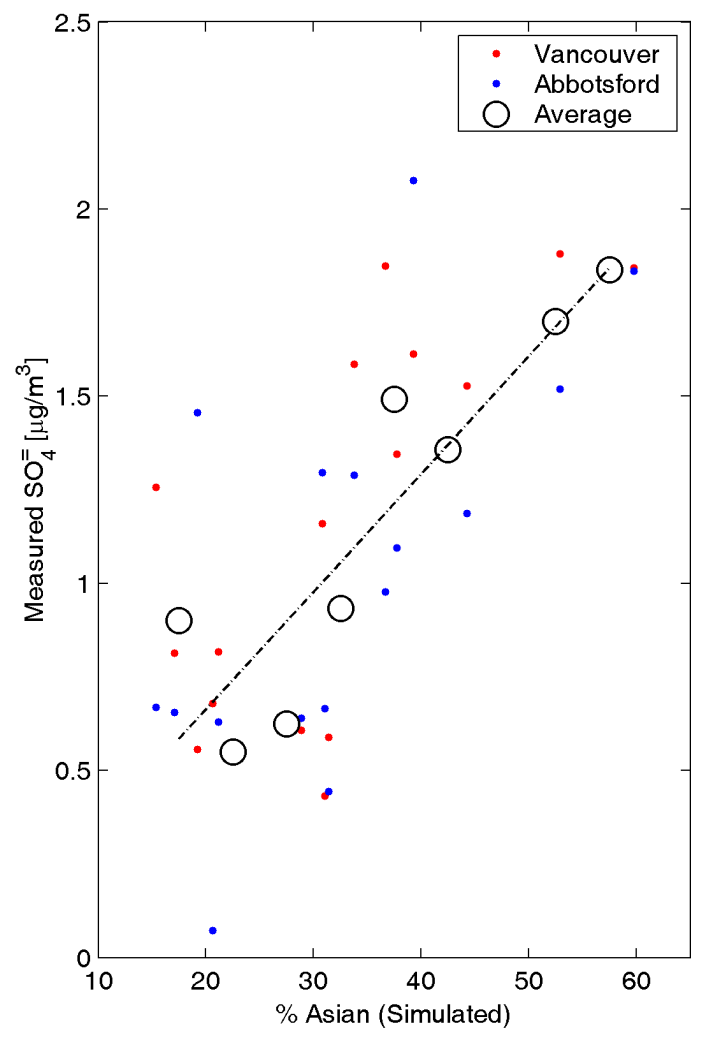

Fig. 11. The influence of Asian $\mathrm{SO}_{4}^{=}$on coastal western Canadian surface concentrations during April-May 2006. Black circles denote mean filter pack sulfate measurements from Canada's National Air Pollution Network sites in Vancouver and Abbotsford as averaged at $5 \%$ intervals of percent Asian $\mathrm{SO}_{4}^{=}$. Dashed line shows linear best fit. Percent Asian sulfate is simulated using the GEOSChem model.

relationship over East Asia. We estimate the average annual growth in East Asian $\mathrm{SO}_{\mathrm{x}}$ emissions to be between 6.2\% using MISR and 9.6\% using MODIS, supporting the bottom-up estimate of an annual increase of 9.9\% from 2000 (Streets et al., 2003) to 2006.

We use this simulation to understand the characteristics of East Asian outflow as measured by the INTEX-B aircraft. Over the Pacific Ocean, Asian outflow of $\mathrm{SO}_{\mathrm{x}}$ is strongest in the lower troposphere, with enhanced $\mathrm{SO}_{4}^{=}$concentrations of $1-1.5 \mu \mathrm{g} / \mathrm{m}^{3}$ observed by the DC- 8 between $700-800 \mathrm{hPa}$. The mean C-130 and Cessna aircraft $\mathrm{SO}_{4}^{=}$measurements of $1-1.5 \mu \mathrm{g} / \mathrm{m}^{3}$ over $600-800 \mathrm{hPa}$ indicate that Asian plumes are often elevated by orographic effects along coastal North America. The simulation generally captures the campaign mean profile shape of DC-8 $\mathrm{SO}_{\mathrm{x}}$, and C-130/Cessna $\mathrm{SO}_{4}^{=}$ measurements, with RMSD of $0.13-0.54 \mu \mathrm{g} / \mathrm{m}^{3}$ (mean bias of $2.5-59 \%$ ). Bias in simulated $\mathrm{SO}_{2}$ oxidation likely contribute to the lower agreement found with respect to the C130 measurements. Simulations without Asian emissions reveal that long-range transport of $\mathrm{SO}_{4}^{=}$dominates campaignmean aircraft measurements in the free troposphere. 
We compare the INTEX-B measurements with aircraft measurements in May 1985 over a similar domain as the $\mathrm{C}-130$. Measured free tropospheric $\mathrm{SO}_{4}^{=}$concentrations increase by $60-90 \%$ from 1985 to 2006 . Sensitivity simulations for 1985 and without East Asian emissions indicate that their relative contribution to $\mathrm{SO}_{4}^{=}$concentrations during April and May between $500-900 \mathrm{hPa}$ increased by $72-85 \%$ due to emission changes as compared to 1985 depending on the specific region.

Comparison of individual plumes with aircraft profiles and MODIS AOD reveals a general consistency, but offsets in time and space. Campaign-mean simulations show that $50 \%$ of the $\mathrm{SO}_{4}^{=}$burden between 1 and $5 \mathrm{~km}$ over Whistler is of anthropogenic Asian origin. These emissions increase surface concentrations along the western Canadian coast by an average $0.31 \mu \mathrm{g} / \mathrm{m}^{3}(\sim 30 \%)$ in spring. This effect is corroborated with surface measurements, where we find an increase of $0.32 \mu \mathrm{g} / \mathrm{m}^{3}$ with each $10 \%$ increase in simulated fraction of Asian $\mathrm{SO}_{4}^{=}$during INTEX-B, with episodic enhancements of more than $1.5 \mu \mathrm{g} / \mathrm{m}^{3}$.

A better understanding of $\mathrm{SO}_{2}$ oxidation is still needed. Previous work (Heald et al., 2006) and our analysis indicate an overestimate in the simulated $\mathrm{SO}_{2}$ oxidation rate. Development of size-resolved aerosol simulations and $\mathrm{SO}_{4}^{=}$instruments that sample larger particles with high time resolution would facilitate model-measurement comparison. Improved understanding of inter-instrument $\mathrm{SO}_{4}^{=}$measurements would be valuable.

Acknowledgements. We thank David Parrish for his helpful suggestions. Rob Buchanan provided professional and tireless piloting of the Cessna during the study. Tragically, Rob lost his life in the crash of the Cessna following the conclusion of the study. Mohammed Wasey, Armand Gaudenzi, Dave Halpin and John Deary provided technical and logistical support. Special thanks to Juniper Buller, Anton Horvath, the Whistler Ski Patrol and Whistler Blackcomb for their support. This work is supported by the Natural Sciences and Engineering Research Council of Canada Special Research Opportunity Program and Environment Canada. Edward J. Dunlea and Jose L. Jimenez were supported by NASA grants NNG04GA67G and NNG06GB03G and NSF grants ATM-0449815 and ATM-0513116. Rodney Weber was funded through NASA grant NNG06GA68G. We thank the MODIS and MISR teams for their level 3 aerosol products and Environment Canada for their NAPS data.

Edited by: H. Singh

\section{References}

Arellano Jr., A. F., Kasibhatla, P. S., Giglio, L., van der Werf, G. R., and Randerson, J. T.: Top-down estimates of global CO sources using MOPITT measurements, Geophys. Res. Lett., 31, L01104, doi:10.1029/2003GL018609, 2004.

Abdou, W. A., Diner, D. J., Martonchik, J. V., Bruegge, C. J., Kahn, R. A., Gaitley, B. J., and Crean, K. A.: Comparison of coincident Multiangle Imaging Spectroradiometer and Moderate Resolution Imaging Spectroradiometer aerosol optical depths over land and ocean scenes containing Aerosol Robotic Network sites, J. Geophys. Res., 110, D10S07, doi:10.1029/2004JD004693, 2005.

Andreae, M. O., Berresheim, H., and Andreae, T. W., Kritz, M. A., Bates, T. S., and Merrill, J. T.: Vertical distribution of dimethylsulfide, sulfur dioxide, aerosol ions, and radon over the northeast Pacific Ocean, J. Atmos. Chem., 6, 149-173, 1988.

Bailey, R., Barrie, L. A., Halsall, C. J., Fellin, P., and Muir, D. C. G.: Atmospheric organochlorine pesticides in the western Canadian Arctic: Evidence of transpacific transport, J. Geophys. Res., 105(D9), 11 805-11811, 2000.

Barrie, L. A., Li, S.-M., Toom, D. L., Landsberger, S., and Sturges, W.: Lower tropospheric measurements of halogens, nitrates, and sulphur oxides during Polar Sunrise Experiment 1992, J. Geophys. Res., 99(D12), 25 453-25 467, 1994.

Benkovitz, C. M., Scholtz, M. T., Pacyna, J., Tarrasón, L., Dignon, J., Voldner, E. C., Spiro, P. A., Logan, J. A., and Graedel, T. E.: Global gridded inventories of anthropogenic emissions of sulfur and nitrogen, J. Geophys. Res., 101(D22), 29 239-29 253, 1996.

Bertschi, I. T., Jaffe, D. A., Jaeglé, L., Price, H. U., and Dennison, J. B.: PHOBEA/ITCT 2002 airborne observations of transpacific transport of ozone, $\mathrm{CO}$, volatile organic compounds, and aerosols to the northeast Pacific: Impacts of Asian anthropogenic and Siberian boreal fire emissions, J. Geophys. Res., 109, D23S12, doi:10.1029/2003JD004328, 2004.

Bey, I., Jacob, D. J., Yantosca, R. M., Logan, J. A., Field, B. D., Fiore, A. M., Li, Q., Liu, H. Y., Mickley, L. J., and Schultz, M. G.: Global modeling of tropospheric chemistry with assimilated meteorology: Model description and evaluation, J. Geophys. Res., 106(D19), 23 073-23 095, 2001.

Bowman, K. P.: Comparison of TRMM precipitation retrievals with rain gauge data from ocean buoys, J. Climate, 18, 178-190, 2005.

Brock, C. A., Hudson, P. K., Lovejoy, E. R., Sullivan, A., Nowak, J. B., Huey, L G., Cooper, O. R., Cziczo, D. J., de Gouw, J., Fehsenfeld, F. C., Holloway, J. S., Hübler, G., Lafleur, B. G., Murphy, D. M., Neuman, J. A., Nicks Jr., D. K., Orsini, D. A., Parrish, D. D., Ryerson, T. B., Tanner, D. J., Warneke, C., Weber, R. J., and Wilson, J. C.: Particle characteristics following cloud-modified transport from Asia to North America, J. Geophys. Res., 109, D23S26, doi:10.1029/2003JD004198, 2004.

Canagaratna, M. R., Jayne, J. T., Jimenez, J. L., Allan, J. D., Alfarra, M. R., Zhang, Q., Onasch, T. B., Drewnick, F., Coe, H., Middlebrook, A., Delia, A., Williams, L. R., Trimborn, A. M., Northway, M. J., DeCarlo, P. F., Kolb, C. E., Davidovits, P., and Worsnop, D. R.: Chemical and microphysical characterization of ambient aerosols with the Aerodyne Aerosol Mass Spectrometer, Mass Spectrom. Rev., 26, 185-222, 2007.

Cofer, W. R., Collins, V. G., and Talbot, R. W.: Improved aqueous scrubber for collection of soluble atmospheric trace gases, Environ. Sci. Technol., 19, 557-560, 1985.

Corbett, J. J., Wang, C., Winebrake, J. J., and Green, E., Allocation 
and forecasting of global ship emissions, Clean Air Task Force Report, 2007.

DeCarlo, P. F., Kimmel, J. R., Trimborn, A., Northway, M. J., Jayne, J. T., Aiken, A. C., Gonin, M., Fuhrer, K., Horvath, T., Docherty, K. S., Worsnop, D. R., and Jimenez, J. L.: Field-deployable, high-resolution, time-of-flight aerosol mass spectrometer, Anal. Chem., 78, 8281-8289, 2006.

Dubovik, O., Lapyonok, T., Kaufman, Y. J., Chin, M., Ginoux, P., and Sinyuk, A.: Retrieving global sources of aerosols from satellites using inverse modeling, Atmos. Chem. Phys., 8, 209-250, 2008,

http://www.atmos-chem-phys.net/8/209/2008/.

Eisinger, M. and Burrows, J. P.: Tropospheric sulfur dioxide observed by the ERS-2 GOME instrument, Geophys. Res. Lett., 25(22), 4177-4180, 1998.

Fairlie, T. D., Jacob, D. J., and Park, R. J., The impact of transpacific transport of mineral dust in the United States, Atmos. Environ., 41, 1251-1266, 2007.

Fu., T.-M., Jacob, D. J., Palmer, P. I., Chance, K., Wang, Y. X., Barletta, B., Blake, D. R., Stanton, J. C., and Pilling, M. J.: Space-based formaldehyde measurements as constraints on volatile organic compound emissions in east and south Asia and implications for ozone, J. Geophys. Res., 112, D06312, doi:10.1029/2006JD007853, 2007.

Harner, T, Shoeib, M., Kozma, M., Gobas, F. A. P. C., and Li, S. M.: Hexachlorocyclohexanes and endosulfans in urban, rural and high altitude air samples in the Fraser Valley, British Columbia: Evidence for trans-Pacific transport, Environ. Sci. Technol., 39, 724-731, 2005.

Heald, C. L., Jacob, D. J., Jones, D. B., Palmer, P. I., Logan, J. A., Streets, D. G., Sachse, G. W., Gille, J. C., Hoffman, R. N., and Nehrkorn, T.: Comparative inverse analysis of satellite (MOPITT) and aircraft (TRACE-P) observations to estimate Asian sources of carbon monoxide. J. Geophys. Res., 109, D23306, doi:10.1029/2004JD005185, 2004.

Heald, C. L., Jacob, D. J., Park, R. J., Russel, L. M., Huebert, B. J., Seinfeld, J. H., Liao, H., and Weber, R.: A large organic aerosol source in the free troposphere missing from current models, Geophys. Res. Let., 32, L18809, doi:10.1029/2005GL023831, 2005.

Heald, C. L., Jacob, D. J., Park, R. J., Alexander, B., Fairlie, T. D., Yantosca, R. M., and Chu, D. A.: Transpacific transport of Asian anthropogenic aerosols and its impact on surface air quality in the United States, J. Geophys. Res., 111, D14310, doi:10.1029/2005JD006847, 2006.

Huey, L. G., Tanner, D. J., Slusher, D. L., Dibb, J. E., Arimoto, R., Chen, G., Davis, D., Buhr, M. P., Nowak, J. B., Mauldin, R. L. III, Eisele, R. L., and Kosciuch, E.: CIMS measurements of $\mathrm{HNO}_{3}$ and $\mathrm{SO}_{2}$ at the South Pole during ISCAT 2000, Atmos. Environ., 38, 5411-5421, 2004.

Jacob, D. J.: Heterogeneous chemistry and tropospheric ozone, Atmos. Environ., 34, 2131-2159, 2000.

Jacob, D. J., Crawford, J. H., Kleb, M. M., Connors, V. S., Bendura, R. J., Raper, J. L., Sachse, G. W., Gille, J. C., Emmons, L., and Heald, C. L.: Transport and Chemical Evolution over the Pacific (TRACE-P) aircraft mission: Design, execution, and first results, J. Geophys. Res., 108(D20), 9000, doi:10.1029/2002JD003276, 2003.

Jaffe, D., Anderson, T., Covert, D., Kotchenruther, R., Trost, B., Danielson, J., Simpson, W., Berntsen, T., Karlsdottir, S., Blake,
D., Harris, J., Carmichael, G., and Uno, I.: Transport of Asian air pollution to North America, Geophys. Res. Lett., 26(6), 711714, 1999.

Jayne, J. T., Leard, D., Zhang, X., Daivovits, P., Smith, K. A., Kolb, C. E., and Worsnop D. R.: Development of an aerosol mass spectrometer for size and composition analysis of submicron particles, Aerosol Sci. Technol., 33(1), 49-70, 2000.

Jaeglé, L., Steinberger, L., Martin, R.V., and Chance, K.: Global partitioning of NOx sources using satellite observations: Relative roles of fossil fuel combustion, biomass burning and soil emissions, Faraday Discuss., 130, 407-423, 2005.

Jimenez, J. L., Jayne, J. T., Shi, Q., Kolb, C. E., Worsnop, D. R., Yourshaw, I., Seinfeld, J. H., Flagan, R. C., Zhang, X., Smith, K. A., Morris, J. W., and Davidovits, P.: Ambient aerosol sampling using the Aerodyne Aerosol Mass Spectrometer, J. Geophys. Res., 108(D7), 8425, doi:10.1029/2001JD001213, 2003.

Jordan, C. E., Dibb, J. E., Anderson, B. E., and Fuelberg, H. E.: Uptake of nitrate and sulfate on dust aerosols during TRACE-P, J. Geophys. Res., 108(D21), 8817, doi:10.1029/2002JD003101, 2003.

Kahn, R. A., Gaitley, B. J., Martonchik, J. V., Diner, D. J., and Crean, K. A.: Multiangle Imaging Spectroradiometer (MISR) global aerosol optical depth validation based on 2 years of coincident Aerosol Robotic Network (AERONET) observations, J. Geophys. Res., 110, D10S04, doi:10.1029/2004JD004706, 2005.

Kaufman, Y. J., Tanré, D., Remer, L. A., Vermote, E. F., Chu, D. A., and Holben, B. N.: Operational remote sensing of tropospheric aerosol over the land from EOS moderate resolution imaging spectroradiometer, J. Geophys. Res., 102, 17 051-17 061, 1997.

Khokhar, M. F., Frankenberg, C., Van Roozendael, M., Beirle, S., Kühl, S., Richter, A., Platt, U., and Wagner, R.: Satellite observations of atmospheric $\mathrm{SO}_{2}$ from volcanic eruptions during the time-period of 1996-2002, Adv. Space Res., 36, 879-887, 2005.

Kim, S., Huey, L. G., Stickel, R. E., Tanner, D. J., Crawford, J. H., Olson, J. R., Chen, G., Brune, W. H., Ren, X., Lesher, R., Wooldridge, P. J., Bertram, T. H., Perring, A., Cohen, R. C., Lefer, B., Shetter, R. E., Avery, M., Diskin, G., and Sokolik, I.: Measurement of pernitric acid in the free troposphere, J. Geophys. Res., 112, D12S01, doi:10.1029/2006JD007676, 2007.

Krotkov, N. A., Carn, S. A., Krueger, A. J., Bhartia, P. K., and Yang, K.: Band residual difference algorithm for retrieval of SO/sub $2 /$ from the aura ozone monitoring instrument (OMI), IEEE Tr. Geosci. Remote, 44(5), 1259-1266, 2006.

Kuhns, H., Knipping, E. M., and Vukovich, J. M.: Development of a United States-Mexico emissions inventory for the Big Bend Regional Aerosol and Visibility Observational (BRAVO) study, J. Air Waste Manag. Assoc., 55, 677-692, 2005.

Leue, C., Wenig, M., Wagner, T., Klimm, O., Platt, U., and Jahne, B.: Quantitative analysis of $\mathrm{NO}_{\mathrm{x}}$ emissions from GOME satellite image sequences, J. Geophys. Res., 106(D6), 5493-5505, 2001.

Levy, R. C., Remer, L. A., Mattoo, S., Vermote, E. F., and Kaufman, Y. J.: Second-generation operational algorithm: Retrieval of aerosol properties over land from inversion of Moderate Resolution Imaging Spectroradiometer spectral reflectance, J. Geophys. Res., 112, D13211, doi:10.1029/2006JD007811, 2007.

Liang, Q., Jaeglé, L., Jaffe, D. A., Weiss-Penzias, P., Heckman, A., and Snow, J. A.: Long-range transport of Asian pollution to the northeast Pacific: Seasonal variations and transport path- 
ways of carbon monoxide, J. Geophys. Res., 109, D23S07, doi:1029.2003JD004402, 2004.

Liao, H., Henze, D. K., Seinfeld, J. H., Wu, S., and Mickley, L. J.: Biogenic secondary organic aerosol over the United States: Comparison of climatological simulations with observations, J. Geophys. Res., 112, D06201, doi:10.1029/2006JD007813, 2007.

Liu, H, Jacob, D. J., Bey, I., and Yantosca, R. M.: Constraints from ${ }^{210} \mathrm{~Pb}$ and ${ }^{7} \mathrm{Be}$ on wet deposition and transport in a global threedimensional chemical tracer model driven by assimilated meteorological fields, J. Geophys. Res., 106, D11, 12 109-12 128, 2001.

Liu, J., Mauzerall, D. L., and Horowitz, L. W.: Analysis of seasonal and interannual variability in transpacific transport, J. Geophys. Res., 110, D04302, doi:10.1029/2004JD005207, 2005.

Liu, P. S. K., Deng, S., Smith, K. A., Williams, L. R., Jayne, J. T., Canagaratna, M. R., Moore, K., Onasch, T. B., Worsnop, D. R., and Deshler, T.: Transmission efficiency of an aerodynamic focusing lens system: Comparison of model calculations and laboratory measurements for the Aerodyne Aerosol Mass Spectrometer, Aerosol Sci. Technol., 41, 721-733, 2007.

Liu, J., Mauzerall, D. L., and Horowitz, L. W.: Source-receptor relationships between East Asian sulfur dioxide emissions and Northern Hemisphere sulfate concentrations, Atmos. Chem. Phys. Discuss., 8, 5537-5561, 2008,

http://www.atmos-chem-phys-discuss.net/8/5537/2008/.

Macdonald, A. M., Anlauf, K. G., Leaitch, W. R., and Liu, P. S. K.: Multi-year chemistry of particles and selected traces gases at the Whistler High Elevation Site, EOS Trans., 87(52), AEB-0719, 2006.

Martin, R. V., Jacob, D. J., Chance, K., Kurosu, T. P., Palmer, P. I., and Evans, M. J.: Global inventory of nitrogen oxide emissions constrained by space-based observations of $\mathrm{NO}_{2}$ columns, J. Geophys. Res., 108(D17), doi:10.1029/2003JD003453, $2003 \mathrm{a}$.

Martin, R. V., Jacob, D. J., and Yantosca, R. M.: Global and regional decreases in tropospheric oxidants from photochemical effects of aerosols, J. Geophy. Res., 108(D3), 4097, doi:10.1029/2002JD002622, 2003b.

Martonchik, J. V., Diner, D. J., Crean, K. A., and Bull, M. A.: Regional aerosol retrieval results from MISR, IEEE Trans. Geosci. Remote Sens., 40(7), 1520-1531, 2002.

Massie, S. T., Torres, O., and Smith, S. J.: Total Ozone Mapping Spectrometer (TOMS) observations of increases in Asian aerosol in winter from 1979 to 2000, J. Geophys. Res., 109, D18211, doi:10.1029/2004JD004620, 2004.

McKendry, I. G., Hacker, J. P., Stull, R., Sakiyama, S., Mignacca, D., and Reid, K.: Long-range transport of Asian dust to the Lower Fraser Valley, British Columbia, Canada, J. Geophys. Res., 106(D16), 18 361-18 370, 2001.

McKendry, I. G., Strawbridge, K. B., O’Neill, N. T., Macdonald, A. M., Liu, P. S. K., Leaitch, W. R., Anlauf, K. G., Jaegle, L., Fairlie, T. D., and Westphal, D. L.: Trans-Pacific transport of Saharan dust to western North America: A case study, J. Geophys. Res., 112, D01103, doi:10.1029/2006JD007129, 2007.

McKendry, I. G., Macdonald, A M., Leaitch, W. R., van Donkelaar, A., Zhang, Q., Duck, T., and Martin, R. V.: Trans-Pacific dust events observed at Whistler, British Columbia during INTEX-B, Atmos. Chem. Phys. Discuss., 8, 10 275-10 300, 2008.

McNaughton, C. S., Thornhill, L., Clarke, A. D., Howell, S. G., Pinkerton, M., Anderson, B., Winstead, E., Hudgins, C., Mar- ing, H., Dibb, J. E., and Scheuer, E.: Results from the DC-8 inlet characterization experiment (DICE): Airborne versus surface sampling of mineral dust and sea salt aerosols, Aerosp. Sci. Technol., 40, 136-159, 2007.

Mishchenko, M. L. and Geogdzhayer, I. V.: Satellite remote sensing reveals regional tropospheric aerosol trends, Opt. Ex., 15(12), 7423-7438, 2007.

Müller, J.-F. and Stavrakou, T.: Inversion of $\mathrm{CO}$ and $\mathrm{NO}_{\mathrm{x}}$ emissions using the adjoint of the IMAGES model, Atmos. Chem. Phys., 5, 1157-1186, 2005, http://www.atmos-chem-phys.net/5/1157/2005/.

Olivier, J. G. J., Berdowski, J. J. M., Peters, J. A. H. W., Bakker, J., Visschedijk, A. J. H., and Bloos, J. P. J.:Applications of EDGAR. Including a description of EDGAR 3.2: reference database with trend data for 1970-1995, RIVM, Bilthoven, RIVM report 773301 001/NRP report 410200 051, 2001.

Palmer, P. I., Jacob, D. J., Fiore, A. M., Martin, R. V., Chance, K., and Kurosu, T. P.: Mapping isoprene emissions over North America using formaldehyde column observations from space, J. Geophys. Res., 108(D6), 4180, doi:10.1029/2002JD002153, 2003.

Park, R. J., Jacob, D. J., Chin, M., and Martin, R. V.: Sources of carbonaceous aerosols over the United States and implications for natural visibility, J. Geophys. Res., 108(D12), D15204, doi:10.1029/2002JD003190, 2003.

Park, R. J., Jacob, D. J., Field, B. D., and Yantosca, R. M.: Natural and transboundary pollution influences on sulphate-nitrateammonium aerosols in the United States: Implications for policy, J. Geophys. Res., 109, D15204, doi:10.1029/2003JD004473, 2004.

Park, R. J., Jacob, D. J., Palmer, P. I., Clarke, A. D., Weber, R. J., Zondlo, M. A., Eisele, F. L., Bandy, A. R., Thornton, D. C., Sachse, G. W., and Bond, T.: Export efficiency of black carbon aerosol in continental outflow: Global implications, J. Geophys. Res., 110, D11205, doi:10.1029/2004JD005432, 2005.

Park, R. J., Jacob, D. J., Naresh, K., and Yantosca, R. M.: Regional visibility statistics in the United States: Natural and transboundary pollution influences, and implications for the Regional Haze Rule, Atmos. Environ., 40, 5405-5423, 2006.

Parrish, D. D., Hahn, C. J., Williams, E. J., Norton, R. B., Fehsenfeld, F. C., Singh, H. B., Shetter, J. D., Gandrud, B. W., and Ridley, B. A.: Indications of photochemical histories of Pacific air masses from measurements of atmospheric tracer species at Pt. Arena, California, J. Geophys. Res., 97, 15 883-15 901, 1992.

Pétron, G., Granier, C., Khattatov, B., Yudin, V., Lamarque, J.-F., Emmons, L., Gille, J., and Edwards, D. P.: Monthly CO surface sources inventory based on the 20002001 MOPITT satellite data, Geophys. Res. Let., 31, L21107, doi:10.1029/2004GL020560, 2004.

Peltier, R. E., Hecobian, A. H., Weber, R. J., Stohl, A., Atlas, E. L., Riemer, D. D., Blake, E., Apel, E., Campos, T., and Karl, T.: Investigating the sources and atmospheric processes of fine particles from Asia and North America measured during INTEXB, Atmos. Chem. Phys., 8, 1835-1853, 2008, http://www.atmos-chem-phys.net/8/1835/2008/.

Prospero, J. M., Ginoux, P., Torres, O., Nicholson, S. E., and Gill, T. E.: Environmental characterization of global sources of atmospheric soil dust identified with the NIMBUS 7 Total Ozone Mapping Spectrometer (TOMS) absorbing aerosol product, Rev. 
Geophys., 40(1), 1002, doi:10.1029/2000RG000095, 2002.

Remer, L. A., Kaufman, Y. J., Tanré, D., Mattoo, S., Chu, D. A., Martins, J. V., Li, R-R., Ichoku, C., Levy, R. C., Kleidman, R. G., Eck, T. F., Vermote, E., and Holben, B. N.: The MODIS aerosol algorithm, products and validation, J. Atmos. Sci., 62, 947-973, 2005.

Richter, A., Burrows, J. P., Nüß, H., Granier, C., and Niemeier, U.: Increase in Tropospheric nitrogen dioxide levels over China observed from space, Nature, 437, 129-132, 2005.

Rupakheti, M., Leaitch, R. W., Lohmann, U., Hayden, K., Brickell, P., Lu, G., Li, S.-M., Toom-Sauntry, D., Bottenheim, J. W., Brook, J. R., Vet, R., Jayne, J. T., and Worsnop, D. R.: An intensive study of the size and composition of submicron atmospheric aerosols at a rural site in Ontario, Canada. Aero. Sci. Tech., 39, 722-736, 2005.

Sirois, A., and Barrie, L. A.: Artic lower tropospheric aerosol trends and composition at Alert Canada: 1980-1995, J. Geophys. Res., 104, 11 599-11 618, 1999.

Song, C. H., Kim, C. M., Lee, Y. J., Carmichael, G. R., Lee, B. K., and Lee, D. S.: An evaluation of reaction probabilities of sulfate and nitrate precursors onto East Asian dust particles, J. Geophys. Res., 112, D18206, doi:10.1029/2006JD008092, 2007.

Streets, D. G. and Waldhoff, S. T.: Present and future emissions of air pollutants in China: $\mathrm{SO}_{2}, \mathrm{NO}_{\mathrm{x}}$ and $\mathrm{CO}$, Atmos. Environ., 34, 363-374, 2000.

Streets, D. G., Tsai, N. Y., Akimoto, H., and Oka, K.: Sulfur dioxide emissions in Asia in the period 1985-1997, Atmos. Environ., 34, 4413-4424, 2000b.

Streets, D. G., Bond, T. C., Carmichael, G. R., Fernandes, S. D., Fu, Q., He, D., Klimont, Z., Nelson, S. M., Tsai, N. Y., Wang, M. Q., Woo, J.-H., and Yarber, K. F.: An inventory of gaseous and primary aerosol emissions in Asia in the year 2000, J. Geophys. Res., 108(D21), 8809, doi:10.1029/2002JD003093, 2003.
Streets, D. G., Zhang, Q., Wang, L., He, K., Hao, J., Wu, Y., Tang, Y., and Carmichael, G. R.: Revisiting China's CO emissions after the Transport and Chemical Evolution over the Pacific (TRACE-P) mission: Synthesis of inventories, atmospheric modeling, and observations, J. Geophys. Res., 111, D14306, doi:10.1029/2006JD007118, 2006.

van $\operatorname{der}$ A, R. J., Peters, D. H. M. U., Eskes, H., Boersma, K. F., van Roozendael, M., De Smedt, I., and Kelder, H. M.: Detection of the trend and seasonal variation in tropospheric NO2 over China, J. Geophys. Res., 111, D12317, doi:10.1029/2005JD006594, 2006.

Vestreng, V., Myhre, G., Fagerli, H., Reis, S., and Tarrasón L.: Twenty-five years of continuous sulphur dioxide emission reduction in Europe, Atmos. Chem. Phys., 7, 3663-3683, 2007, http://www.atmos-chem-phys.net/7/3663/2007/.

Weber, R. J., Orsini, D., Daun, Y., Lee, Y.-N., Klotz, P. J., and Brechtel, F.: A particle-into-liquid collector for rapid measurement of aerosol bulk chemical composition, Aerosp. Sci. Technol., 35, 718-727, 2001.

Yu., H., Remer, L. A., Chin., M., Bian, H., Kleidman, R. G., and Diehl, T.: A satellite-based assessment of transpacific transport of pollution aerosol, J. Geophys. Res., 113, D14S12, doi:10.1029/2007JD009349, 2008.

Zhang, Q., Streets, D. G., He, K., Wang, Y., Richter, A., Burrows, J. P., Uno, I., Jang, C. J., Chen, D., Yao, Z., and Lei, Y.: NOx emission trends for China, 1995-2004: The view from the ground and the view from space, J. Geophys. Res., 112, D22306, doi:10.1029/2007JD008684, 2007. 